\title{
Effect of soil aeration on root morphology and photosynthetic characteristics of potted tomato plants (Solanum lycopersicum) at different $\mathrm{NaCl}$ salinity levels
}

\author{
Yuan $\mathrm{Li}^{1}$, Wenquan $\mathrm{Niu}^{2,3,4^{*}}$ (D), Xiaoshu Cao ${ }^{1}$, Jingwei Wang ${ }^{2,3}$, Mingzhi Zhang ${ }^{3}$, Xiaohui Duan ${ }^{1,3}$ and \\ Zhenxing Zhang ${ }^{5,6}$
}

\begin{abstract}
Background: Salt stress is one of the environmental factors that greatly limits crop production worldwide because high salt concentrations in the soil affect morphological responses and physiological and metabolic processes, including root morphology and photosynthetic characteristics. Soil aeration has been reported to accelerate the growth of plants and increase crop yield. The objective of this study was to examine the effects of $3 \mathrm{NaCl}$ salinity levels $(28,74$ and $120 \mathrm{mM})$ and 3 aeration volume levels $(2.3,4.6$ and $7.0 \mathrm{~L} /$ pot $)$ versus non-aeration and salinity treatments on the root morphology, photosynthetic characteristics and chlorophyll content of potted tomato plants.

Results: The results showed that both aeration volume and salinity level affected the root parameters, photosynthetic characteristics and chlorophyll content of potted tomato plants. The total length, surface area and volume of roots increased with the increase in aeration volume under each $\mathrm{NaCl}$ stress level. The effect was more marked in the fine roots (especially in $\leq 1 \mathrm{~mm}$ diameter roots). Under each $\mathrm{NaCl}$ stress level, the photosynthetic rate and chlorophyll content of tomato significantly increased in response to the aeration treatments. The net photosynthetic rate and chlorophyll a and t content increased by 39.6, 26.9, and 17.9\%, respectively, at 7.0 L/pot aeration volume compared with no aeration in the $28 \mathrm{mM} \mathrm{NaCl}$ treatment. We also found that aeration could reduce the death rate of potted tomato plants under high salinity stress conditions (120 mM NaCl).
\end{abstract}

Conclusions: The results suggest that the negative effect of $\mathrm{NaCl}$ stress can be offset by soil aeration. Soil aeration can promote root growth and increase the photosynthetic rate and chlorophyll content, thus promoting plant growth and reducing the plant death rate under $\mathrm{NaCl}$ stress conditions.

Keywords: Tomato, Soil aeration, NaCl salinity, Root morphology, Photosynthetic characteristics

\section{Background}

Environmental stresses such as those caused by acid/alkaline/saline soils are the main restricting factors on crop production worldwide [1]. Salinity is one of the major abiotic stress factors that adversely affects crop plant yield and mass. Tuteja's research [2] found that approximately $23 \%$ of cultivated land was affected by salinity. Ashraf's

\footnotetext{
* Correspondence: nwq@vip.sina.com

${ }^{2}$ Institute of Soil and Water Conservation, Northwest A\&F University, No.26 Xinong Road, Yangling, Shaanxi Province 712100, People's Republic of China ${ }^{3}$ Institute of Water-saving Agriculture in Arid Areas of China (IWSA),

Northwest A\&F University, Yangling 712100, Shaanxi, China

Full list of author information is available at the end of the article
}

research [3] indicates that the potential yield losses from salinity are estimated at $20 \%$. The impact of environmental stress around the world caused by salinity is constantly expanding in many parts of the world, particularly in arid and semiarid areas, because agriculture expanding to these regions with modern irrigation practices will exacerbate secondary salinization [4-6]. These problems also occur in China, where it was estimated that approximately 3,693 $\mathrm{hm}^{2}$ of land is saline [7]. It is well known that salinity may have deleterious effects on plant growth, and crop production is low in saline soils. Low concentrations of salt can induce growth retardation in non-halophytic plants, while

(c) The Author(s). 2019 Open Access This article is distributed under the terms of the Creative Commons Attribution 4.0 International License (http://creativecommons.org/licenses/by/4.0/), which permits unrestricted use, distribution, and 
high concentrations can even result in the death of the plant [8-10]. This is mainly due to salt toxicity leading to a decrease in plant water holding capacity, imbalances in nutrient uptake, and the toxicity of ions to plant roots and photosynthesis $[11,12]$.

Currently, the salinity in soils is mainly caused by three kinds of cations $\left(\mathrm{Na}^{+}, \mathrm{Ca}^{2+}, \mathrm{Mg}^{2+}\right)$ and four kinds of anions $\left(\mathrm{CO}_{3}{ }^{2-}, \mathrm{HCO}_{3}{ }^{-}, \mathrm{Cl}^{-}, \mathrm{SO}_{4}{ }^{2-}\right)$ [13]. $\mathrm{NaCl}$ is the most universally distributed type of salt at present and does substantial harm. $\mathrm{NaCl}$ has been shown to inhibit uptake and transport of N, P, K and Ca [14]. Additionally, $\mathrm{NaCl}$ stress leads to reductions in $\mathrm{Zn}$ uptake by plant roots due to $\mathrm{Na}^{+}$competition at the root surface [15]. More remarkably, most saline land suffers from waterlogging [16] or soil compaction [17]. Both of these conditions easily cause hypoxia stress $\left(\right.$ low $\left.\mathrm{O}_{2}\right)$.

Plant roots require sufficient oxygen for the production of ATP from sugars. Through aerobic respiration, $1 \mathrm{~mol}$ glucose can produce $38 \mathrm{~mol}$ ATP. However, under anaerobic conditions, only $2 \mathrm{~mol}$ of ATP can be produced. Therefore, plant roots cannot obtain enough energy to maintain health and normal physiological activity under hypoxic conditions. Second, the metabolites (such as ethanol, lactate, $\mathrm{H}_{2} \mathrm{O}_{2}$, etc.) accumulated during hypoxia are hazardous materials for plants themselves $[18,19]$. In addition, the negative impacts of salinity are severe when the rhizosphere is exposed to hypoxia. The root uptake of $\mathrm{Na}^{+}$and $\mathrm{Cl}^{-}$increases with decreasing $\mathrm{O}_{2}$ concentration in the rhizosphere [20]. $\mathrm{NaCl}$ stress causes greater increases in $\mathrm{Na}^{+}$and $\mathrm{Cl}^{-}$concentrations in the shoots and greater decreases the concentrations of $\mathrm{K}^{+}$[21].

Tomato is a principal vegetable crop due to its worldwide consumption and is adapted to a variety of climates, from temperate to tropical and from arid to humid areas [22]. However, salt stress is a main factor that limits the fruit yields of tomato, because salinity seriously disrupts tomato plant growth at all stages of growth, thus reducing fruit production.

Photosynthesis is the first process to be compromised by salinity. Salt stress leads to a reduction in leaf water potential and both stomatal resistance and mesophyll resistance to gas flows rises, with a subsequent limitation of photosynthetic activity [23, 24]. The reduction of stomatal conductance and photosynthesis under salt stress reduces leaf growth and dry matter [25]. The root system is the main part of the plant to experience soil salinity and likely plays a vital role in coping with soil salts. How salts and hypoxia affect root growth and morphology is of great importance to elucidate the mechanism of plant adaptation processes. Previous studies have shown that salinity reduced the root length density of tomato and the root dry matter reduction under salinity was combined with a root/shoot ratio increase [26, 27].
Artificial aeration has been reported to increase dissolved $\mathrm{O}_{2}$ content and ameliorate the negative effects of hypoxia stress [28-34]. Previous studies strongly suggest that increased access to $\mathrm{O}_{2}$ by aeration has positive impacts on plant growth and physiology. In sandy soil, harvest data showed that bell pepper plants irrigated with aerated water produced $39 \%$ greater weight, than plants irrigated with non-aerated water [35]. Since aeration increases the concentration of $\mathrm{O}_{2}$ in the root zone, it is reasonable to infer that the observed positive effects are indirectly linked to the response of the plant root and photosynthetic system.

In Northwest China, hypoxic conditions are usually accompanied by salt stress. With a constantly increasing population, the shortage of land resources has become an urgent problem in China [36]. In recent years, in order to produce more fruits, farmers have been forced to plant tomatoes in saline land [37]. Nevertheless, most of the previous studies have dealt with artificial aeration and salinity separately, and little is known about the potential interaction between these two factors in tomato plants. The objective of this study was to quantify the effects of non-aeration versus 3 aeration volumes in potted tomato plants at $3 \mathrm{NaCl}$ stress levels. Specifically, we examined data on plant growth, leaf photosynthetic rate and root morphology.

\section{Results \\ Growth rate}

The effects of different aeration treatments on the growth rates of plant height and stem diameter under certain $\mathrm{NaCl}$ conditions are shown in Table 1. The results showed that root zone aeration had a significant effect on the growth rates of plant height from 0 to $30 \mathrm{DAT}$ and of stem diameter from 70 to 90 DAT. $\mathrm{NaCl}$ stress had a significant effect on the growth rates of plant height from 0 to 70 DAT and of stem diameter from 0 to 30 and 70-90 DAT. The ANOVA F-value showed that the interaction of $\mathrm{NaCl}$ stress and aeration level was not significant for plant growth rate at 0-90 DAT. Throughout the growth period, the plant height growth rate exhibited a trend of initial increase (0-70 DAT) followed by a decrease (70-90 DAT) under CK and $\mathrm{S}_{1}$ treatments, and the plant height growth rate increased with tomato growth (0-90 DAT) under $S_{2}$ treatment. Except for the stem diameter growth rate at 50-70 DAT, all the treatment combinations of aeration volume and $\mathrm{NaCl}$ stress were significant at the $5 \%$ level. From 0 to 70 DAT, the plant height growth rate decreased with increasing $\mathrm{NaCl}$ stress under each aeration treatment. The highest plant height growth rate was observed in the CK, $\mathrm{S}_{1} \mathrm{~A}_{2}$ and $\mathrm{S}_{2} \mathrm{~A}_{2}$ treatments during $0-50,50-70$, and $70-90$ 
Table 1 plant growth rate of potted single tomato plants measured at 0, 30, 50, 70 and 90 days after transplanting (DAT) for the 4 aeration levels at the $3 \mathrm{NaCl}$ stress levels

\begin{tabular}{|c|c|c|c|c|c|c|c|c|}
\hline \multirow[t]{2}{*}{ Treatments } & \multicolumn{4}{|c|}{ Growth rate of plant height/ (cm/Day) } & \multicolumn{4}{|c|}{ Growth rate of stem diameter/ (mm/Day) } \\
\hline & 0-30DAT & 30-50DAT & 50-70DAT & 70-90DAT & 0-30DAT & 30-50DAT & 50-70DAT & 70-90DAT \\
\hline CK & $0.99 a$ & $1.26 a$ & $1.80 a b$ & $0.84 a b$ & $0.79 a$ & $0.48 a b$ & $0.15 a$ & $0.54 \mathrm{bcde}$ \\
\hline$S_{1} A_{0}$ & $0.74 \mathrm{bcd}$ & $0.83 a b c$ & $1.63 a b c$ & $1.23 a b$ & $0.33 \mathrm{bcd}$ & $0.24 a b c$ & $0.49 a$ & $0.81 \mathrm{abc}$ \\
\hline$S_{1} A_{1}$ & $0.83 a b$ & $0.76 \mathrm{bcd}$ & $1.80 \mathrm{ab}$ & $1.53 a b$ & $0.38 \mathrm{bc}$ & $0.33 a b c$ & $0.48 a$ & $1.06 a b$ \\
\hline $\mathrm{S}_{1} \mathrm{~A}_{2}$ & $0.96 a$ & $1.01 \mathrm{ab}$ & $1.85 \mathrm{a}$ & $1.21 \mathrm{ab}$ & $0.73 a$ & $0.32 \mathrm{abc}$ & $0.47 a$ & $0.78 a b c$ \\
\hline $\mathrm{S}_{1} \mathrm{~A}_{3}$ & $0.78 b c$ & $1.06 a b$ & $1.34 a b c d$ & $1.31 \mathrm{ab}$ & $0.54 a b$ & $0.58 a$ & $0.41 \mathrm{a}$ & $0.83 a b c$ \\
\hline $\mathrm{S}_{2} \mathrm{~A}_{0}$ & $0.48 \mathrm{e}$ & 0.36de & $1.19 \mathrm{bcd}$ & $1.30 a b$ & $0.25 \mathrm{~cd}$ & $0.08 \mathrm{bc}$ & $0.67 a$ & $0.13 e$ \\
\hline $\mathrm{S}_{2} \mathrm{~A}_{1}$ & $0.63 \mathrm{cde}$ & 0.44 cde & 0.93def & $1.63 a b$ & $0.35 \mathrm{bcd}$ & $0.04 c$ & $0.61 a$ & 0.31cde \\
\hline $\mathrm{S}_{2} \mathrm{~A}_{2}$ & 0.62 cde & $0.48 \mathrm{cde}$ & 1.39abcd & $1.70 \mathrm{a}$ & $0.40 \mathrm{bc}$ & $0.41 \mathrm{abc}$ & $0.35 a$ & 0.69abcd \\
\hline $\mathrm{S}_{2} \mathrm{~A}_{3}$ & 0.60de & $0.49 \mathrm{cde}$ & $1.05 \mathrm{cde}$ & $1.15 a b$ & $0.32 \mathrm{bcd}$ & $0.45 \mathrm{abc}$ & $0.19 a$ & $0.32 \mathrm{cde}$ \\
\hline $\mathrm{S}_{3} \mathrm{~A}_{0}$ & $0.51 \mathrm{e}$ & $0.24 \mathrm{e}$ & $0.30 \mathrm{~g}$ & $0.60 \mathrm{~b}$ & $0.09 d$ & $0.32 \mathrm{abc}$ & $0.17 a$ & 0.30 cde \\
\hline $\mathrm{S}_{3} \mathrm{~A}_{1}$ & $0.53 e$ & $0.29 \mathrm{e}$ & $0.43 \mathrm{fg}$ & $0.87 a b$ & $0.23 \mathrm{~cd}$ & $0.20 a b c$ & $0.49 a$ & $0.19 \mathrm{de}$ \\
\hline $\mathrm{S}_{3} \mathrm{~A}_{2}$ & $0.57 e$ & 0.34de & $0.48 \mathrm{efg}$ & $1.20 a b$ & $0.26 \mathrm{~cd}$ & $0.47 a b c$ & $0.16 a$ & $1.11 \mathrm{a}$ \\
\hline $\mathrm{S}_{3} \mathrm{~A}_{3}$ & $0.55 e$ & $0.21 \mathrm{e}$ & $0.29 \mathrm{~g}$ & $0.94 a b$ & $0.23 \mathrm{~cd}$ & $0.23 a b c$ & $0.31 a$ & 0.44 cde \\
\hline \multicolumn{9}{|l|}{ F-value } \\
\hline Aeration volume (A) & $3.396^{*}$ & $0.637 \mathrm{~ns}$ & $1.528 \mathrm{~ns}$ & $0.755 \mathrm{~ns}$ & $4.040^{*}$ & $2.685 \mathrm{~ns}$ & $1.243 \mathrm{~ns}$ & $3.446^{*}$ \\
\hline Salinity level (S) & $37.611^{* *}$ & $22.114^{* *}$ & $31.761^{* *}$ & $2.078 \mathrm{~ns}$ & $19.615^{* *}$ & $1.725 \mathrm{~ns}$ & $1.970 \mathrm{~ns}$ & $7.479^{* *}$ \\
\hline$A \times S$ & 0.827 ns & $0.341 \mathrm{~ns}$ & $0.521 \mathrm{~ns}$ & $0.371 \mathrm{~ns}$ & $0.861 \mathrm{~ns}$ & $1.177 \mathrm{~ns}$ & $0.866 \mathrm{~ns}$ & 2.197 ns \\
\hline
\end{tabular}

Note: Values followed by different small letters in the same column meant significant differences at $p<5 \%$. ANOVA F-value for main and interaction effects were not significant $(\mathrm{ns})$ or significant at $\leq 5 \%(*)$ and $\leq 1 \%$ level $(* *)$

DAT, respectively, and the highest stem diameter growth rate was observed in the $\mathrm{CK}, \mathrm{S}_{1} \mathrm{~A}_{3}$ and $\mathrm{S}_{3} \mathrm{~A}_{2}$ treatments during 0-30, 30-50, and 70-90 DAT, respectively.

\section{Total root length, surface area, volume and number of forks}

The results of the ANOVA indicated that both aeration and salinity had significant effects on total root length, surface area and root volume of potted tomato plants (Table 2). Two-way interaction effects were highly significant on total root length, root surface area and number of forks, but not on the total root volume of the potted tomato plants. As shown in Table 2, with no aeration, plants under each $\mathrm{NaCl}$ stress level had significantly lower total root length, surface area, volume and number of forks than those in the non- $\mathrm{NaCl}$ stress treatment $(\mathrm{CK})$. This indicates that the tomato root is sensitive to $\mathrm{NaCl}$ stress. Nevertheless, with no aeration, the root length, surface area, volume and number of forks of potted tomato plants under the $S_{1}$ treatment were $17.8,20.9,22.0$, and $37.2 \%$ higher than of those under the $S_{2}$ treatment, respectively. The total root length, surface area, volume and number of forks increased with the increasing aeration volume under the $\mathrm{S}_{1}$ treatment. Although all the plants in the $\mathrm{S}_{3} \mathrm{~A}_{0}$ treatment combination died, under the $S_{2}$ and $S_{3}$ treatments, root length, surface area, volume and number of forks of potted tomato plants showed first an increase and then a decrease when the aeration volume increased; under the $\mathrm{A}_{2}$ treatment, the 4 variables reached their maximum. Except in the $S_{2} A_{1}$ treatment combination, the root length, surface area, volume and number of forks under the $S_{1}$ and $S_{2}$ salinity levels with aeration treatment were higher than those under CK.

\section{Root length, surface area, and volume distribution by diameter}

The main treatment and interaction effects on root length, surface area and volume by range of diameter are shown in Table 3. The aeration volume had no significant effect on the root surface area for diameters over $2 \mathrm{~mm}$. The ANOVA showed that both salinity and soil aeration treatments significantly affected root length and surface area distribution by root diameter of potted tomato plants (Table 3). The experimental results showed that the aeration volume and the salinity level had significant effects on root length and surface area distribution for diameters $0<\mathrm{D} \leq 0.1,0.1<\mathrm{D} \leq 0.2, \quad 0.2<\mathrm{D} \leq 0.5, \quad 0.5<\mathrm{D} \leq 1.0$ and $1.0<\mathrm{D} \leq 2.0$ but had no significant effect on root volume for diameters over $2 \mathrm{~mm}$. All two way interactions effects 
Table 2 total root length, surface area, volume and forks of potted single tomato plants measured at mature period (155 DAT) for the 4 aeration levels at the $3 \mathrm{NaCl}$ stress levels

\begin{tabular}{|c|c|c|c|c|}
\hline Treatments & $\begin{array}{l}\text { Root length } \\
(\mathrm{cm} / \text { plant })\end{array}$ & $\begin{array}{l}\text { Root surface area } \\
\left(\mathrm{cm}^{2} / \text { plant }\right)\end{array}$ & $\begin{array}{l}\text { Root volume } \\
\left(\mathrm{cm}^{3} / \text { plant }\right)\end{array}$ & forks \\
\hline CK & $8045 \mathrm{de}$ & $717 \mathrm{~cd}$ & $5.18 \mathrm{bcd}$ & 63822de \\
\hline $\mathrm{S}_{1} \mathrm{~A}_{0}$ & $5644 \mathrm{fg}$ & 489ef & 3.50def & $37185 \mathrm{fg}$ \\
\hline $\mathrm{S}_{1} \mathrm{~A}_{1}$ & 8505 cde & $851 b c$ & $7.06 a b$ & $82247 \mathrm{~cd}$ \\
\hline $\mathrm{S}_{1} \mathrm{~A}_{2}$ & $10272 \mathrm{bc}$ & $916 \mathrm{bc}$ & $6.63 a b c$ & $100433 b c$ \\
\hline $\mathrm{S}_{1} \mathrm{~A}_{3}$ & $15040 a$ & 1300a & $9.16 a$ & $138341 a$ \\
\hline $\mathrm{S}_{2} \mathrm{~A}_{0}$ & $6649 e f$ & 591de & 4.27cde & 51007ef \\
\hline $\mathrm{S}_{2} \mathrm{~A}_{1}$ & 7267 ef & $747 \mathrm{~cd}$ & $6.34 b c$ & 71791de \\
\hline $\mathrm{S}_{2} \mathrm{~A}_{2}$ & $11516 b$ & $1034 b$ & $7.48 a b$ & $112764 b$ \\
\hline $\mathrm{S}_{2} \mathrm{~A}_{3}$ & $9595 \mathrm{bcd}$ & $850 b c$ & $6.23 b c$ & $83795 \mathrm{~cd}$ \\
\hline $\mathrm{S}_{3} \mathrm{~A}_{0}$ & - & - & - & - \\
\hline $\mathrm{S}_{3} \mathrm{~A}_{1}$ & 1988 & 158 & 1.02 & 11289 \\
\hline $\mathrm{S}_{3} \mathrm{~A}_{2}$ & 3923gh & $333 \mathrm{fg}$ & 2.28ef & $22047 \mathrm{~g}$ \\
\hline $\mathrm{S}_{3} \mathrm{~A}_{3}$ & $2697 \mathrm{~h}$ & $198 \mathrm{~g}$ & $1.21 f$ & $15745 \mathrm{~g}$ \\
\hline \multicolumn{5}{|l|}{ F-value } \\
\hline Aeration volume (A) & $36.001^{* *}$ & $22.764^{* *}$ & $10.778^{* *}$ & $29.807^{* *}$ \\
\hline Salinity level (S) & $67.687^{* *}$ & $50.030^{* *}$ & $25.847^{* *}$ & $49.161^{* *}$ \\
\hline$A \times S$ & $9.798^{* *}$ & $5.559^{* *}$ & $2.118 \mathrm{~ns}$ & $5.852^{* *}$ \\
\hline
\end{tabular}

Note: Values followed by different small letters in the same column meant significant differences at $p<5 \%$. ANOVA F-value for main and interaction effects were not significant (ns) or significant at $\leq 5 \%(*)$ and $\leq 1 \%$ level $(* *)$. Under the $S_{3} A_{0}$ treatment plants all died, So the $S_{3} A_{0}$ row is empty. Multiple comparison can't be performed for $\mathrm{S}_{3} \mathrm{~A}_{1}$ treatment because only 1 plant survived

Table 3 Two-way ANOVA of Aeration volume (A), Salinity level (S) and the A $\times$ S interaction on root length (cm/plant), surface area $\left(\mathrm{cm}^{2} /\right.$ plant $)$ and volume $\left(\mathrm{cm}^{3} /\right.$ plant) distribution by root diameter

\begin{tabular}{|c|c|c|c|c|}
\hline & Root diameter (D) mm & Aeration volume (A) & Salinity level (S) & $A \times S$ \\
\hline \multirow[t]{6}{*}{ Root length } & $0-0.1$ & $34.642^{* *}$ & $50.032^{* *}$ & $7.990^{* *}$ \\
\hline & $0.1-0.2$ & $23.235^{* *}$ & $47.477^{* *}$ & $8.981^{* *}$ \\
\hline & $0.2-0.5$ & $16.141^{* *}$ & $43.765^{* *}$ & $5.879^{* *}$ \\
\hline & $0.5-1.0$ & $12.696^{* *}$ & $28.400^{* *}$ & $2.458 \mathrm{~ns}$ \\
\hline & $1.0-2.0$ & $7.176^{* *}$ & $12.649^{* *}$ & $0.805 \mathrm{~ns}$ \\
\hline & $>2.0$ & $3.752^{*}$ & $4.764^{*}$ & $0.301 \mathrm{~ns}$ \\
\hline \multirow[t]{6}{*}{ Root surface area } & $0-0.1$ & $34.675^{* *}$ & $51.435^{* *}$ & $8.355^{* *}$ \\
\hline & $0.1-0.2$ & $23.132^{* *}$ & $48.499^{* *}$ & $9.162^{* *}$ \\
\hline & $0.2-0.5$ & $15.997^{* *}$ & $43.234^{* *}$ & $5.369^{* *}$ \\
\hline & $0.5-1.0$ & $12.492^{* *}$ & $27.429^{* *}$ & $2.377 \mathrm{~ns}$ \\
\hline & $1.0-2.0$ & $6.941^{* *}$ & $12.180^{* *}$ & $0.762 \mathrm{~ns}$ \\
\hline & $>2.0$ & $2.894 \mathrm{~ns}$ & $4.028^{*}$ & $0.320 \mathrm{~ns}$ \\
\hline \multirow[t]{6}{*}{ Root volume } & $0-0.1$ & $35.306^{* *}$ & $53.769^{* *}$ & $8.872^{* *}$ \\
\hline & $0.1-0.2$ & $22.956^{* *}$ & $49.463^{* *}$ & $9.337^{* *}$ \\
\hline & $0.2-0.5$ & $15.728^{* *}$ & $42.319^{* *}$ & $4.867^{* *}$ \\
\hline & $0.5-1.0$ & $12.253^{* *}$ & $26.422^{* *}$ & $2.289 \mathrm{~ns}$ \\
\hline & $1.0-2.0$ & $6.704^{* *}$ & $11.704^{* *}$ & $0.724 \mathrm{~ns}$ \\
\hline & $>2.0$ & 1.794 ns & $3.025 \mathrm{~ns}$ & $0.336 \mathrm{~ns}$ \\
\hline
\end{tabular}


on root length, surface area and volume of tomato plants were highly significant for diameters $0<\mathrm{D} \leq 0.1,0.1<\mathrm{D} \leq$ $0.2,0.2<\mathrm{D} \leq 0.5 \mathrm{~mm}$, but not on root length, surface area and volume for diameters over $0.5 \mathrm{~mm}$.

The results of the ANOVA indicated that the treatment effects of aeration volume and salinity level and their interaction all had a significant influence on these morphological observations. Treatment effects on these morphological traits were more marked at the lower diameter ranges, and the influence of salinity is larger than that of aeration volume (Table 3).

The response pattern for root length by diameter was identical to that for root length. Under the no-aeration treatment, $\mathrm{NaCl}$ stress resulted in decreased root length at each diameter range. Nevertheless, the root lengths were not significantly different from the $S_{1}$ and $S_{2}$ marginal means (Fig. 1). Under the $S_{1}$ treatment, root length increased with increasing aeration volume for root diameters $0<\mathrm{D} \leq 0.1 \mathrm{~mm}, 0.1<\mathrm{D} \leq 0.2 \mathrm{~mm}, 0.2<\mathrm{D} \leq 0.5 \mathrm{~mm}$ and $0.5<\mathrm{D} \leq 1.0 \mathrm{~mm}$, The values with no aeration were 2736, 1251, 1239 and $319 \mathrm{~cm}$, and with $\mathrm{V}_{3}$ were 7598 , 3155,2958 and $964 \mathrm{~cm}$, which were 178, 152, 139 and $202 \%$ greater than the values for the no-aeration treatment for root length distribution at each diameter range, respectively. Under the $S_{2}$ treatment, the root length for diameters $0<\mathrm{D} \leq 0.1 \mathrm{~mm}, 0.1<\mathrm{D} \leq 0.2 \mathrm{~mm}, 0.2<\mathrm{D} \leq 0.5$ $\mathrm{mm}, \quad 0.5<\mathrm{D} \leq 1.0 \mathrm{~mm}$ and $1.0<\mathrm{D} \leq 2.0 \mathrm{~mm}$ initially increased and then decreased as the soil aeration volume increased and reached a maximum under the $\mathrm{A}_{2}$ treatment. The root length values for potted tomato plant aeration under $\mathrm{A}_{2}$ treatment for each diameter were 5476, 2558, 2392, 771 and $226 \mathrm{~cm}$, respectively. Under heavy $\mathrm{NaCl}$ stress, the no-aeration treatment plants all died. Nevertheless, the root length distribution at each diameter range initially increased and then decreased as the aeration frequency increased, reaching a maximum under the $\mathrm{A}_{2}$ treatment. The maximum values for each diameter range were1900, 950, 845, 173, 27 and $11 \mathrm{~cm}$, respectively.

Figures 2 and 3 show a similar response pattern for root surface area and volume for each diameter (Table 3). In general, soil aeration improved the root surface area and volume at each diameter range. Nevertheless, salinity stress decreased the root surface area and volume for each diameter, especially in the $S_{3}$ treatment. The highest values of root surface area for root diameters of $0<\mathrm{D} \leq$ $0.1 \mathrm{~mm}, 0.1<\mathrm{D} \leq 0.2 \mathrm{~mm}, 0.2<\mathrm{D} \leq 0.5 \mathrm{~mm}$ and $0.5<\mathrm{D} \leq$ $1.0 \mathrm{~mm}$ were observed in the $S_{1} A_{3}$ treatment combination, and the values for each diameter were 128, 140, 288 and $206 \mathrm{~cm}^{2}$, respectively (Fig. 2). Similarly, the root surface area initially increased, and then decreased when the soil aeration volume increased and reached a maximum under the $\mathrm{A}_{2}$ treatment for diameters $0<\mathrm{D} \leq 0.1 \mathrm{~mm}, 0.1<\mathrm{D} \leq$ $0.2 \mathrm{~mm}, 0.2<\mathrm{D} \leq 0.5 \mathrm{~mm}, 0.5<\mathrm{D} \leq 1.0 \mathrm{~mm}$ and $1.0<\mathrm{D} \leq$
$2.0 \mathrm{~mm}$. Similarly, increasing aeration volume progressively increased root volume for root diameters $0<\mathrm{D} \leq 0.1 \mathrm{~mm}$, $0.1<\mathrm{D} \leq 0.2 \mathrm{~mm}, \quad 0.2<\mathrm{D} \leq 0.5 \mathrm{~mm}$ and $0.5<\mathrm{D} \leq 1.0 \mathrm{~mm}$ under $S_{1}$ treatment (Fig. 3). Differences between the marginal means were significant at the $5 \%$ level, and the values for no aeration were $0.07,0.21,1.00$ and $1.15 \mathrm{~cm}^{3}$ for each diameter range, respectively. Values for each diameter range $\mathrm{V}_{3}$ treatment were $0.19,0.51,2.39$, and 3.65 , which were $167,148,140$, and $218 \%$ greater, respectively, than the value for the no-aeration treatment.

\section{Photosynthetic characteristics}

The results of marginal means for $P_{\mathrm{n}}$ are shown in Fig. $4 \mathrm{a}$, ranging from 2.4 to $11.7 \mu \mathrm{mol} \mathrm{CO} \mathrm{CO}^{-2} \mathrm{~s}^{-1} . P_{\mathrm{n}}$ increased with increasing aeration volume at for 46,108 and 150 DAT at each salinity level. Compared with other treatments, $P_{\mathrm{n}}$ reached a maximum under the $\mathrm{S}_{1} \mathrm{~A}_{3}$ treatment at 46 DAT, whereas at 108 and 150 DAT, $P_{n}$ reached a maximum under $\mathrm{CK}$ treatment. Measurements of $P_{\mathrm{n}}$ under the $\mathrm{S}_{1} \mathrm{~A}_{3}$ treatment were 42,49 and $28 \%$ higher than those under the $\mathrm{S}_{1} \mathrm{~A}_{0}$ treatment at 46 , 108 , and 150 DAT, respectively. Under the $\mathrm{S}_{2} \mathrm{~A}_{3}$ treatment, measurements of $P_{\mathrm{n}} 83,20$ and $36 \%$ higher than those under the $\mathrm{S}_{2} \mathrm{~A}_{0}$ treatment at 46,108 , and 150 DAT, respectively. Nevertheless, $P_{\mathrm{n}}$ decreased as salinity increased at each aeration level. The $G_{\mathrm{s}}$ under the $S_{1}$ salinity level with aeration treatment was higher than that with no aeration at 108 and 150 DAT (Fig. 4b). Except for the $\mathrm{S}_{1} \mathrm{~A}_{3}$ treatment combination, potted tomato plants under all the treatments at 108 DAT showed the highest $T_{\mathrm{r}}$ values (Fig. 4c). At 46 DAT, the $T_{\mathrm{r}}$ of potted tomato plants decreased with increasing salinity level. The IWUE of potted tomato plants was lower at 108 DAT than at 46 and 150 DAT (Fig. 4 d). $S_{1} A_{2}$ treatment at 46 DAT, $\mathrm{S}_{1} \mathrm{~A}_{3}$ treatment at $108 \mathrm{DAT}$ and CK treatment at 150 DAT showed the highest values for IWUE. The IWUE under $\mathrm{S}_{1} \mathrm{~A}_{2}$ and $\mathrm{S}_{1} \mathrm{~A}_{3}$ treatments was higher than that of $\mathrm{CK}$ at each measurement.

\section{Chlorophyll content}

Table 4 shows that all the combinations had significant impacts on total chlorophyll (Chl. t), chlorophyll a (Chl. a) and chlorophyll b (Chl. b) contents at 46 DAT (fruit setting stage) and 108 DAT (fruit enlargement stage). The Chl. a content was higher at 108 DAT than at 46 DAT under CK and each aeration treatment with $S_{1}$ and $S_{2}$. The results showed that, except in for the $S_{3} A_{0}$ and $\mathrm{S}_{3} \mathrm{~A}_{1}$ treatment combinations, the contents of Chl. a, Chl. b and Chl. $t$ at 108 DAT were higher than those at 46 DAT. As shown in Table 4, at both 46 and 108 DAT, the content of Chl. a increased with increasing aeration volume at each salinity level. Nevertheless, all the values 
Table 4 chlorophyll a, chlorophyll b and total chlorophyll of potted single tomato plants measured at 46 and 108 days after transplanted (DAT) for the 4 aeration levels at the $3 \mathrm{NaCl}$ stress levels

\begin{tabular}{|c|c|c|c|c|c|c|}
\hline \multirow[t]{2}{*}{ Treatments } & \multicolumn{2}{|c|}{ Chl. a / $\left(\mathrm{mg} \cdot \mathrm{g}^{-1}\right)$} & \multicolumn{2}{|c|}{ Chl. b / $\left(\mathrm{mg}^{\prime} \cdot \mathrm{g}^{-1}\right)$} & \multicolumn{2}{|c|}{$\mathrm{Chl}$ t/ $\left(\mathrm{mg} \cdot \mathrm{g}^{-1}\right)$} \\
\hline & 46DAT & 108DAT & 46DAT & 108DAT & 46DAT & 108DAT \\
\hline CK & $2.27 a$ & $2.94 a$ & $0.81 a$ & $1.14 a b c$ & $3.08 a$ & $4.07 a$ \\
\hline $\mathrm{S}_{1} \mathrm{~A}_{0}$ & 1.63abcd & $2.12 \mathrm{abc}$ & $0.55 \mathrm{bcde}$ & $1.22 \mathrm{abc}$ & $2.18 a b c$ & $3.35 \mathrm{ab}$ \\
\hline$S_{1} A_{1}$ & 1.81abcd & $2.29 a b c$ & $0.67 \mathrm{abcd}$ & $1.21 \mathrm{abc}$ & $2.48 a b$ & $3.51 \mathrm{ab}$ \\
\hline $\mathrm{S}_{1} \mathrm{~A}_{2}$ & $2.09 a$ & $2.41 \mathrm{ab}$ & $0.70 a b c$ & $1.27 a b c$ & $2.78 \mathrm{a}$ & $3.68 a b$ \\
\hline$S_{1} A_{3}$ & $2.16 a$ & $2.60 \mathrm{ab}$ & $0.78 a b$ & 0.99abc & $2.93 a$ & $3.59 a b$ \\
\hline $\mathrm{S}_{2} \mathrm{~A}_{0}$ & 1.75abcd & $1.83 a b c$ & 0.61abcde & $1.13 a b c$ & $2.36 a b c$ & $2.96 a b c$ \\
\hline $\mathrm{S}_{2} \mathrm{~A}_{1}$ & $1.92 \mathrm{ab}$ & 2.27abc & $0.65 \mathrm{abcd}$ & $1.53 a b$ & $2.57 a b$ & $3.81 \mathrm{ab}$ \\
\hline $\mathrm{S}_{2} \mathrm{~A}_{2}$ & 1.88abc & $2.36 a b$ & $0.66 a b c d$ & $1.00 \mathrm{abc}$ & $2.54 a b$ & $3.35 a b$ \\
\hline $\mathrm{S}_{2} \mathrm{~A}_{3}$ & $2.04 a$ & $2.45 \mathrm{ab}$ & $0.69 a b c$ & $1.77 a$ & $2.73 a$ & $4.22 \mathrm{a}$ \\
\hline $\mathrm{S}_{3} \mathrm{~A}_{0}$ & $1.14 d$ & $0.61 c$ & $0.38 \mathrm{e}$ & $0.47 c$ & $1.52 \mathrm{C}$ & $1.08 c$ \\
\hline $\mathrm{S}_{3} \mathrm{~A}_{1}$ & $1.21 \mathrm{~cd}$ & $1.03 \mathrm{bc}$ & 0.51 cde & $0.60 c$ & $1.72 b c$ & $1.63 \mathrm{bc}$ \\
\hline $\mathrm{S}_{3} \mathrm{~A}_{2}$ & $1.27 \mathrm{bcd}$ & $1.26 a b c$ & 0.44de & $0.83 b c$ & $1.71 b c$ & 2.09abc \\
\hline $\mathrm{S}_{3} \mathrm{~A}_{3}$ & 1.65abcd & $1.97 a b$ & 0.58abcde & $1.22 \mathrm{a}$ & $2.23 a b c$ & $3.18 a$ \\
\hline \multicolumn{7}{|l|}{ F-value } \\
\hline Aeration volume $(A)$ & $2.480 \mathrm{~ns}$ & $1.481 \mathrm{~ns}$ & $2.880 \mathrm{~ns}$ & $1.716 \mathrm{~ns}$ & $2.637 \mathrm{~ns}$ & $2.257 \mathrm{~ns}$ \\
\hline Salinity level (S) & $10.369^{* *}$ & $6.299^{* *}$ & $10.403^{* *}$ & $4.351^{*}$ & $10.785^{* *}$ & $7.798^{* *}$ \\
\hline$A \times S$ & $0.255 \mathrm{~ns}$ & $0.180 \mathrm{~ns}$ & $0.280 \mathrm{~ns}$ & $2.111 \mathrm{~ns}$ & $0.236 \mathrm{~ns}$ & $0.579 \mathrm{~ns}$ \\
\hline
\end{tabular}

Note: Values followed by different small letters in the same column meant significant differences at $\mathrm{p}<5 \%$. ANOVA F-value for main and interaction effects were not significant (ns) or significant at $\leq 5 \%\left({ }^{*}\right)$ and $\leq 1 \%$ level $\left({ }^{* *}\right)$

under each salinity treatment were lower than that of CK. Similarly, the contents of Chl. b at 46 DAT increased with increasing aeration volume at each salinity level, with CK having the maximum value of $0.81 \mathrm{mg} \cdot \mathrm{g}^{-1}$ and $\mathrm{S}_{3} \mathrm{~A}_{0}$ having the minimum value of $0.38 \mathrm{mg} \cdot \mathrm{g}^{-1}$. At 108 DAT, maximum values of both Chl. $\mathrm{b}$ and Chl. $\mathrm{t}$ contents were observed in the $\mathrm{S}_{2} \mathrm{~A}_{3}(\mathrm{Chl} . \mathrm{b}=1.77$, Chl. $\left.\mathrm{t}=4.22 \mathrm{mg} \cdot \mathrm{g}^{-1}\right)$ and $\mathrm{S}_{3} \mathrm{~A}_{3}$ (Chl. $\mathrm{b}=1.22$, Chl. $\mathrm{t}=3.18$ $\mathrm{mg} \cdot \mathrm{g}^{-1}$ ) treatment combinations. Contents of Chl. $\mathrm{t}$ increased when the soil aeration volume increased, and reached a maximum under the $\mathrm{S}_{1} \mathrm{~A}_{2}, \mathrm{~S}_{1} \mathrm{~A}_{3}$ and $\mathrm{S}_{2} \mathrm{~A}_{3}$ treatment combinations at 46 DAT (Table 4). The ANOVA results showed that while salinity was significant for Chl. a, Chl. b and Chl. t at both 46 and 108 DAT, the aeration volume was not significant. The effect of aeration volume on promoting Chl. a, Chl. b and Chl. $\mathrm{t}$ at 46 DAT is more significant than that at 108 DAT. Interaction analysis found that combinations of aeration volume and salinity level had no significant impacts on the contents of Chl. a, Chl. b and Chl. $\mathrm{t}$ at both 46 and 108 DAT.

\section{Discussion}

There are several factors that affect plant growth, such as soil moisture, nutrients, salinity, temperature, oxygen content and the mechanical impedance of the plant rhizosphere [38]. Our investigation has shown that $\mathrm{NaCl}$ salinity inhibited tomato growth. The $P_{\mathrm{n}}$ and root morphology of tomato plants significantly increased in response to aeration under $\mathrm{NaCl}$ salinity conditions. Therefore, soil aeration strongly promotes plant growth.

\section{$\mathrm{NaCl}$ salinity inhibited tomato growth}

In response to $\mathrm{NaCl}$ toxicity, roots can change their architecture $[1,12,39,40]$. The results of this experiment showed that root morphology (length, surface area, volume, number of forks and tips) decreased significantly with increasing concentrations of $\mathrm{NaCl}(28-120$ $\mathrm{mM}$ ) when compared with the root morphology under the no- $\mathrm{NaCl}$ treatment, especially in thin $(\mathrm{D} \leq 0.5 \mathrm{~mm})$ roots. Our result is in accordance with previous studies of root morphology response to $\mathrm{NaCl}$ salt stress in tomato, rice, euonymus and wheat [40-43]. Various reasons for the reduced root growth under salt stress are possible. High concentrations of salts in soils account for large decreases in the length and surface area of plant roots and are accompanied by a low uptake of salinity, water, nutrients, etc. Lin [44] reported that $\mathrm{NaCl}$ salt stress increased cell-wall peroxidase activity and 
$\mathrm{H}_{2} \mathrm{O}_{2}$ levels. Exogenous $\mathrm{H}_{2} \mathrm{O}_{2}$ and peroxidase were found to inhibit plant root growth.

Our study finds that $\mathrm{NaCl}$ treatments had a significant influence on the proportion of root length for 0.1-0.2 $\mathrm{mm}$ and $0.5-2.0 \mathrm{~mm}$ diameter roots (Table 5) but had no significant effect on the proportion of root length for $0-0.1 \mathrm{~mm}$ and $>2.0 \mathrm{~mm}$ diameter roots. Previous studies observed an increase in the percentage of thick roots and a decreased percentage of fine roots under saline conditions in black spruce and jack pine [45]. Our findings were not consistent with those of previous studies. The different effects of salinity on the proportion of roots of different diameters can also depend on plant species or the tested soil type.

Many studies showed a strong negative correlation between salt concentration and photosynthesis [27, 46, 47]. Bethke's research [23] found that both $\mathrm{Na}^{+}$and $\mathrm{Cl}^{-}$have a direct effect on the photosynthetic apparatus because they reduce the efficiency of ribulose-1 5-bisphosphate carboxylase (Rubisco) in the Calvin cycle. Similarly, our results showed that salt can restrain the growth of tomato (Table 1). Photosynthesis was reduced with increasing concentrations of $\mathrm{NaCl}$ (Fig. 4). This conclusion is consistent with previous studies in tomato [48] and tobacco [9].

High $G_{\mathrm{s}}$ in plants means higher $\mathrm{CO}_{2}$ diffusion into the leaf, thereby favoring higher photosynthetic rates, resulting in higher fruit yields [49]. Under salinity stress, a distinct decrease in the $G_{\mathrm{s}}$ and consistent reductions in $P_{\mathrm{n}}$ and $T_{\mathrm{r}}$ lead the plant to obtain the maximum water use efficiency [50]. The photosynthesis of tomato was deeply reduced, so the stressed plants had a lower amount of fixed carbon $\left(\mathrm{CO}_{2}\right)$ to utilize for plant growth. Our results suggest that $\mathrm{NaCl}$ stress decreases $G_{\mathrm{s}}$ and photosynthetic activity, which may inhibit whole-plant growth. Koyro [50] suggested that this behavior is an adaptive mechanism to cope with salt, especially during periods of high transpiration. The moderate salt level $(74 \mathrm{mM} \mathrm{NaCl})$ reduced the total chlorophyll by $27.3 \%$ compared with the control plants at 108 DAT (Table 4). It also depressed the $P_{\mathrm{n}}$ by 46.6 , 64.2 and $63.2 \%$ compared with the control plants at 46 , 108 and 150 DAT, respectively (Fig. 4). These results indicate that $\mathrm{NaCl}$ stress depressed the photosynthetic capacity of leaves, which might lead to the suppression of photosynthate from leaves to other tissues. This tendency is more pronounced at higher salt levels. We also found that tomato could not survive at $120 \mathrm{mM} \mathrm{NaCl}$. Concentrated salt depositions in the soil generate a low water potential zone in the soil, making it increasingly difficult for the plant to acquire both water and nutrients [1]. Additionally, the accumulated toxins often lead to cell death, which might also contribute to the death of the whole plant [51].

Table 5 Proportion of root length by diameter to experimental factors, Aeration volume (A) and Salinity level (S)

\begin{tabular}{|c|c|c|c|c|c|c|}
\hline \multirow[t]{2}{*}{ treatments } & \multicolumn{6}{|c|}{ Proportion (\%) of root length by diameter (mm) } \\
\hline & $0-0.1$ & $0.1-0.2$ & $0.2-0.5$ & $0.5-1.0$ & $1.0-2.0$ & $>2.0$ \\
\hline$\overline{C K}$ & $47.85 a b$ & $22.51 \mathrm{bcd}$ & $21.56 a b$ & $6.39 a b c$ & $1.47 a b c d$ & $0.21 b$ \\
\hline$S_{1} A_{0}$ & $48.65 a b$ & $22.20 \mathrm{bcd}$ & $22.00 \mathrm{ab}$ & $5.72 b c$ & $1.21 \mathrm{bcd}$ & $0.23 a b$ \\
\hline$S_{1} A_{1}$ & $44.12 b$ & $20.99 \mathrm{~cd}$ & $23.18 a$ & $8.57 a$ & $2.57 a b$ & $0.56 a b$ \\
\hline $\mathrm{S}_{1} \mathrm{~A}_{2}$ & 49.40ab & $21.07 \mathrm{~cd}$ & $20.32 \mathrm{ab}$ & $6.90 \mathrm{abc}$ & $1.93 a b c$ & $0.38 \mathrm{ab}$ \\
\hline $\mathrm{S}_{1} \mathrm{~A}_{3}$ & $50.55 a b$ & $21.07 \mathrm{~cd}$ & $19.81 b$ & $6.48 a b c$ & $1.76 a b c d$ & $0.33 a b$ \\
\hline $\mathrm{S}_{2} \mathrm{~A}_{0}$ & 45.72ab & $25.59 a$ & $21.84 a b$ & $5.23 c$ & $1.29 \mathrm{bcd}$ & $0.32 \mathrm{ab}$ \\
\hline $\mathrm{S}_{2} \mathrm{~A}_{1}$ & 45.91ab & $20.18 d$ & $22.33 a b$ & $8.04 a b$ & $2.81 a$ & $0.73 a$ \\
\hline $\mathrm{S}_{2} \mathrm{~A}_{2}$ & 47.77ab & $22.19 \mathrm{bcd}$ & 20.83ab & $6.84 a b c$ & $2.04 a b c$ & $0.32 \mathrm{ab}$ \\
\hline $\mathrm{S}_{2} \mathrm{~A}_{3}$ & $51.04 a b$ & $21.38 \mathrm{~cd}$ & $19.39 b$ & $6.00 \mathrm{abc}$ & 1.75abcd & $0.45 a b$ \\
\hline $\mathrm{S}_{3} \mathrm{~A}_{0}$ & - & - & - & - & - & - \\
\hline $\mathrm{S}_{3} \mathrm{~A}_{1}$ & 58.24 & 19.24 & 17.30 & 3.93 & 0.86 & 0.43 \\
\hline $\mathrm{S}_{3} \mathrm{~A}_{2}$ & 48.66ab & 24.29ab & $21.63 a b$ & $4.43 \mathrm{~cd}$ & $0.69 \mathrm{~cd}$ & $0.29 a b$ \\
\hline $\mathrm{S}_{3} \mathrm{~A}_{3}$ & $57.80 \mathrm{a}$ & $23.19 b c$ & $15.92 \mathrm{C}$ & $2.23 d$ & $0.48 d$ & $0.38 a b$ \\
\hline \multicolumn{7}{|l|}{ F-value } \\
\hline Aeration volume (A) & $6.210^{* *}$ & $9.107^{* *}$ & $8.528^{* *}$ & $5.599 * *$ & $4.448^{*}$ & 2.502 \\
\hline Salinity level (S) & 1.470 & $6.145^{* *}$ & 0.844 & $6.333^{* *}$ & $3.492^{*}$ & 0.257 \\
\hline$A \times S$ & 1.531 & 2.604 & 2.029 & 0.292 & 0.026 & 0.190 \\
\hline
\end{tabular}

Note: Values followed by different small letters in the same column meant significant differences at $p<5 \%$. ANOVA F-value for main and interaction effects were not significant (ns) or significant at $\leq 5 \%\left({ }^{*}\right)$ and $\leq 1 \%$ level $(* *)$ 
Soil aeration strongly promotes root growth, $P_{\mathrm{n}}$ and chlorophyll content of tomato plants under $\mathrm{NaCl}$ salinity conditions

Soil aeration is an important but often unheeded site factor for plant growth. Like salinity, hypoxia often reduces transpiration and nutrient uptake and inhibits plant growth [52]. Previous research has shown that tomato roots are especially vulnerable to low levels of oxygen in soil $[53,54]$. Soil aeration can effectively promote redoxase enzyme activity and root metabolism, thereby enhancing nutrient absorption and accelerating the growth and yield of plants $[31,55,56]$. To date, there are no reports in the literature specifically examining the sensitivity of tomato plants in salinized soil to aeration and how this may impact root growth and photosynthetic characteristics. However, such information would have high practical value and would be especially important in greenhouses. As we know, soil aeration can speed up the gas exchange process and increase the oxygen content in soil. The high oxygen content in soil could ensure that the physiological activity of the root occurs smoothly [34, 57]. The basic physiology of high $\mathrm{NaCl}$ stress and soil compaction stress overlap with each other. A high $\mathrm{NaCl}$ concentration in the soil can alter the basic texture of the soil, resulting in decreased soil porosity and consequently reduced soil aeration and water conductance. Plants utilize several mechanisms to reduce the negative effects of hypoxia and salt stress. These include signaling pathways controlled by ethylene, abscisic acid (ABA) and reactive oxygen species [58]. For plants to survive, one of the fastest responses to environmental stress is the closing of stomatal pores on the leaf surfaces. Stomatal closure due to ABA accumulation in leaf tissues has been a prolific research field for many years. Stomata regulate the uptake of $\mathrm{CO}_{2}$ for photosynthesis and the loss of water vapor during transpiration [59]. Stella demonstrated that leaf and stem dry matter reduction can be associated with a reallocation of photosynthates to the roots mediated by ABA signaling [60]. ABA induces the production of hydrogen peroxide $\left(\mathrm{H}_{2} \mathrm{O}_{2}\right)$ in guard cells, which in turn activates $\mathrm{Ca}^{2+}$ channels to pump $\mathrm{Ca}^{2+}$ across the plasma membrane, increasing cytosolic $\mathrm{Ca}^{2+}$ and resulting in $\mathrm{Ca}^{2+}$-dependent stomatal closure. The rapid catabolism of ABA in leaves prevents the accumulation of ABA, allowing stomata to open as soon as water conditions return to favorable levels [61, 62]. However, there are no reports in the literature specifically examining the sensitivity of tomato plants in salinized soil to aeration. Previous studies have shown that "reduced photosynthesis and stomatal closure are common responses to floodinginduced deficiencies in soil oxygen" [63]. Else's research [64] also found that "stomatal closure has been linked to a rise in the concentration of bulk aba in the leaves under flooding". Our results showed that $\mathrm{NaCl}$ stress significantly decreased root length, surface area, volume, $P_{\mathrm{n}}$ and $G_{\mathrm{s}}$. These variables were enhanced by artificial soil aeration. Therefore, we speculated that soil aeration may decrease the concentration of ABA. Lower concentrations of ABA can promote $G_{\mathrm{s}}$ and $P_{\mathrm{n}}$, which may promote whole plant growth.

In this experiment, the soil texture was clay loam. Plastic film mulch and no drainage holes at the bottom of the plastic barrel reduced the aeration of the soil. Rhizosphere hypoxia negatively influenced shoot and root growth, which is consistent with previous research showing that hypoxia decreases the growth of roots and shoots [21]. Root respiration has been shown to be improved by aeration when plants are grown in clay loam. Root morphology (total root length, surface area, volume and number of forks) was significantly enhanced by aeration at each salinity level. This positive effect of aeration on root morphology was mainly evident in the $S_{1}$ treatment. This was mainly because both hypoxia and salinity conditions cause increased $\mathrm{Na}^{+}$and $\mathrm{Cl}^{-}$concentrations in the shoot, due initially to increased rates of transport. These increased concentrations in the shoots have adverse effects on plant growth and survival [21]. The positive effect of aeration on root morphology at each salinity level in the clay loam soil may be due to the alleviation of $\mathrm{O}_{2}$ deficiency in the rhizosphere.

It was found that root characteristics had a significant positive correlation with $P_{\mathrm{n}}, G_{\mathrm{s}}$ and Chl. a (Table 6). In this study, both hypoxia and salinity depressed plant growth. The two factors easily lead to a reduction in the root system and photosynthetic characteristics. Our previous studies have shown that soil aeration increased the root length and surface area of muskmelon in clay soils [34]. Salt stress increases abscisic acid synthesis in the root zone, but a favorable soil gas environment reduces it while reducing the abscisic acid contents in leaves [65]. There was a negative correlation between abscisic acid and stomatal resistance. In this study, it is reasonable to infer that root zone aeration might lead to the reduction of abscisic acid synthesis in roots and transport from roots to leaves, and the reduction of abscisic acid in leaves can directly promote $G_{\mathrm{s}}$ (Table 6), thereby providing enough raw material $\left(\mathrm{CO}_{2}\right)$ for the photosynthesis of tomato plants. In addition, Chl. a, root length and surface area increasing with increased aeration might improve the $P_{\mathrm{n}}$ and uptake of water and nutrients at each salinity level. 
Table 6 Simple correlation analysis between root characteristics, photosynthetic characteristics and chlorophyll content of potted tomato

\begin{tabular}{|c|c|c|c|c|c|c|c|c|c|c|c|c|}
\hline Factor & Root length & Root surface area & Root volume & forks & $P_{n}$ & $G_{s}$ & $C_{i}$ & $T_{\mathrm{r}}$ & IWUE & Chl. a & Chl. b & Chl. $(a+b)$ \\
\hline Root length & 1 & & & & & & & & & & & \\
\hline Root surface area & $0.991^{* *}$ & 1 & & & & & & & & & & \\
\hline Root volume & $0.961^{* *}$ & $0.989^{* *}$ & 1 & & & & & & & & & \\
\hline forks & $0.988^{* *}$ & $0.992^{* *}$ & $0.975^{* *}$ & 1 & & & & & & & & \\
\hline$P_{\mathrm{n}}$ & $0.707^{*}$ & $0.696^{*}$ & $0.670^{*}$ & $0.657^{*}$ & 1 & & & & & & & \\
\hline$G_{s}$ & $0.758^{* *}$ & $0.742^{* *}$ & $0.710^{* *}$ & $0.719^{* *}$ & $0.962^{* *}$ & 1 & & & & & & \\
\hline$C_{i}$ & -0.517 & -0.500 & -0.474 & -0.457 & $-0.809^{* *}$ & $-0.740^{* *}$ & 1 & & & & & \\
\hline$T_{\mathrm{r}}$ & 0.388 & 0.444 & 0.496 & 0.383 & $0.622^{*}$ & 0.485 & -0.277 & 1 & & & & \\
\hline IWUE & $0.657^{*}$ & $0.605^{*}$ & 0.536 & $0.616^{*}$ & $0.709^{* *}$ & $0.806^{* *}$ & $-0.770^{* *}$ & -0.083 & 1 & & & \\
\hline Chl. a & $0.764^{* *}$ & $0.773^{* *}$ & $0.769^{* *}$ & $0.747^{* *}$ & $0.882^{* *}$ & $0.822^{* *}$ & $-0.830^{* *}$ & $0.616^{*}$ & $0.635^{*}$ & 1 & & \\
\hline Chl. b & 0.445 & 0.484 & 0.527 & 0.447 & 0.475 & 0.397 & $-0.760^{* *}$ & 0.285 & 0.434 & $0.743^{* *}$ & 1 & \\
\hline Chl. $(a+b)$ & $0.713^{* *}$ & $0.731^{* *}$ & $0.741^{* *}$ & $0.700^{*}$ & $0.811^{* *}$ & $0.742^{* *}$ & $-0.856^{* *}$ & 0.552 & $0.611^{*}$ & $0.980^{* *}$ & $0.862^{* *}$ & 1 \\
\hline
\end{tabular}

Note: ${ }^{*}$ represents a significant difference $(p<0.05)$, and ${ }^{* *}$ represents an extremely significant difference $(p<0.01)$

\section{Conclusions}

Our results demonstrated the following: (1) Aeration volume and salinity affected the total length, surface area, volume and number of forks of potted tomato plant root systems. The 4 root parameters increased with the increase in aeration volume under each $\mathrm{NaCl}$ stress level, and all these parameters decreased with the increase in $\mathrm{NaCl}$ stress; the effect was stronger for the fine-diameter roots. (2) $\mathrm{NaCl}$ stress significantly decreased $P_{\mathrm{n}}, G_{\mathrm{s}}$ and chlorophyll a and b contents.
Aeration volume tended to increase these parameters of the potted tomato under $\mathrm{NaCl}$ stress conditions. Nevertheless, aeration volume did not markedly influence the contents of chlorophyll a and b. (3) Aeration effectively reduced the death rate of potted tomato plants under high salinity stress conditions $(120 \mathrm{mM}$ $\mathrm{NaCl}$ ). The results proved that soil aeration can promote root growth and increase the photosynthetic rate, thus promoting plant growth and reducing the death rate under $\mathrm{NaCl}$ stress conditions.

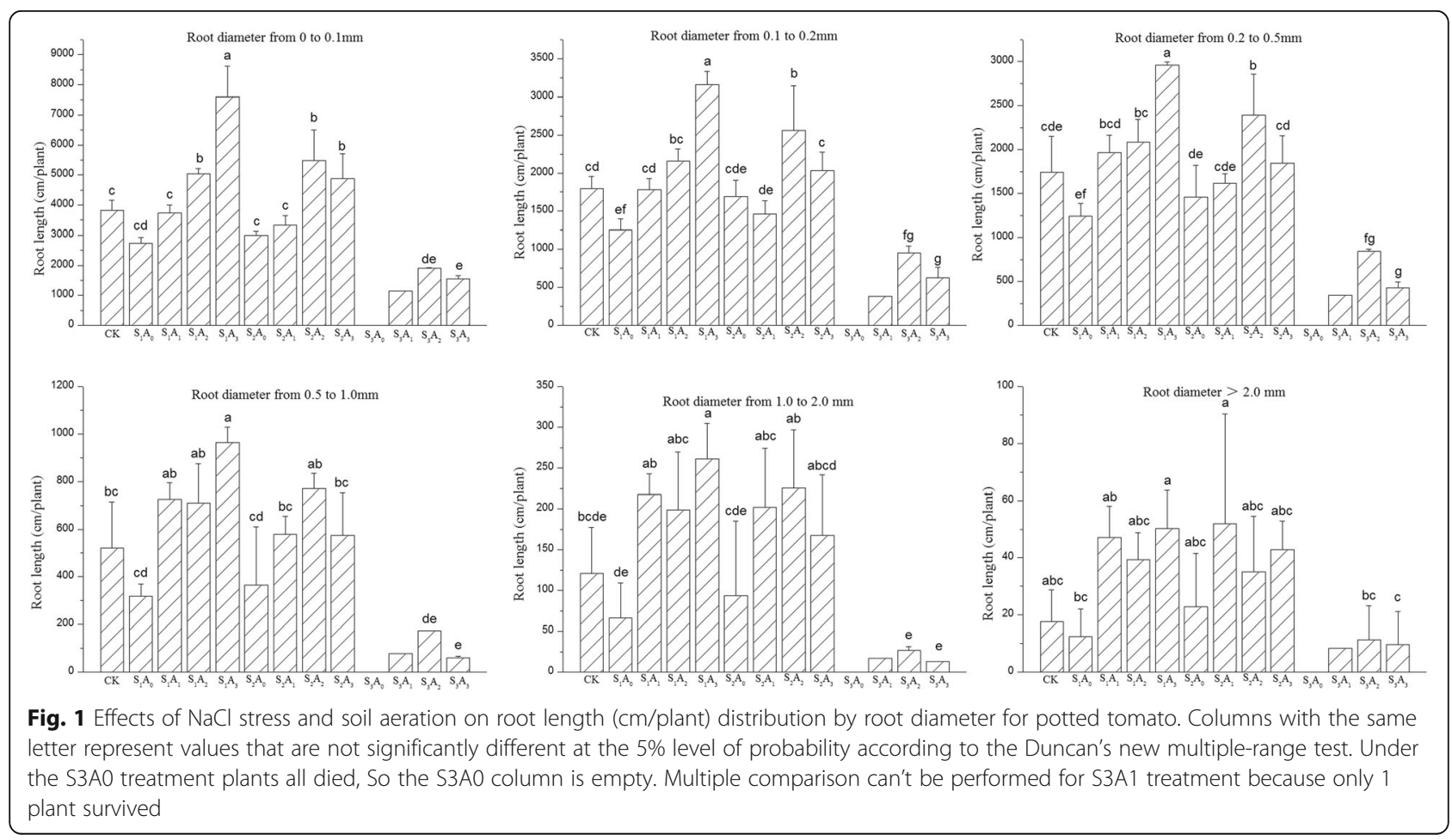




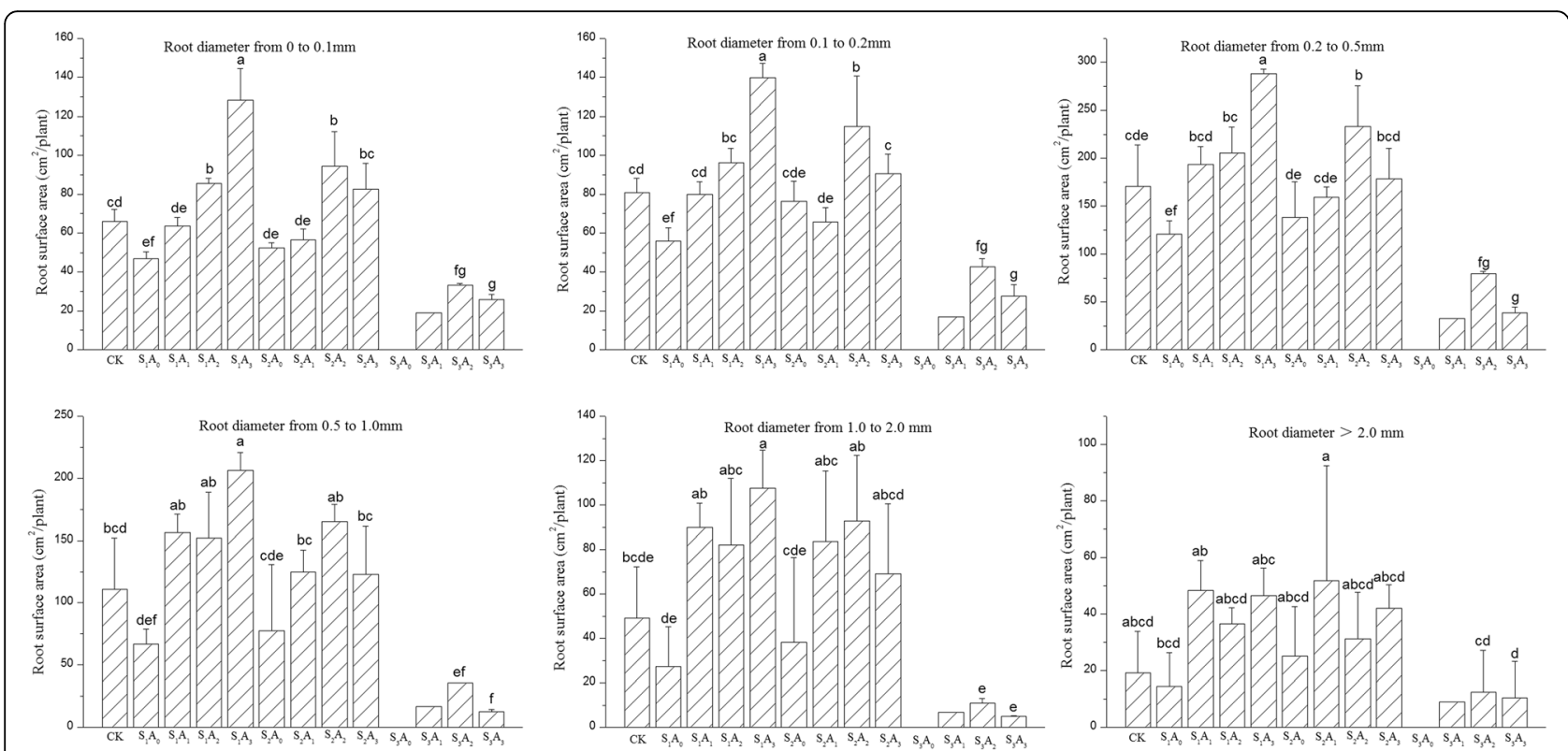

Fig. 2 Effects of $\mathrm{NaCl}$ stress and soil aeration on root surface area (cm2/plant) distribution by root diameter for potted tomato. Columns with the same letter represent values that are not significantly different at the $5 \%$ level of probability according to the Duncan's new multiple-range test. Under the S3A0 treatment plants all died, So the S3A0 column is empty. Multiple comparison can't be performed for S3A1 treatment because only 1 plant survived

\section{Methods}

\section{Site description, plant and soil details}

This study was carried out in a greenhouse of a vegetable farm $\left(34^{\circ} 16^{\prime} \mathrm{N}, 108^{\circ} 04^{\prime} \mathrm{E}\right)$ at Northwest A\&F University, Yangling, Shaanxi Province, West China, from October 2014 to March 2015. The climate of
Yangling is semiarid with an average of 210 frost-free days. The rainfall is between 550 and $650 \mathrm{~mm}$, and the annual sunshine time was $2164 \mathrm{~h}$. The original source of the tomato was New Horizon Facilities Agricultural Development Co. Ltd., Northwest A\&F University, China. The tomato cultivar "Fen-Yu-Yang-
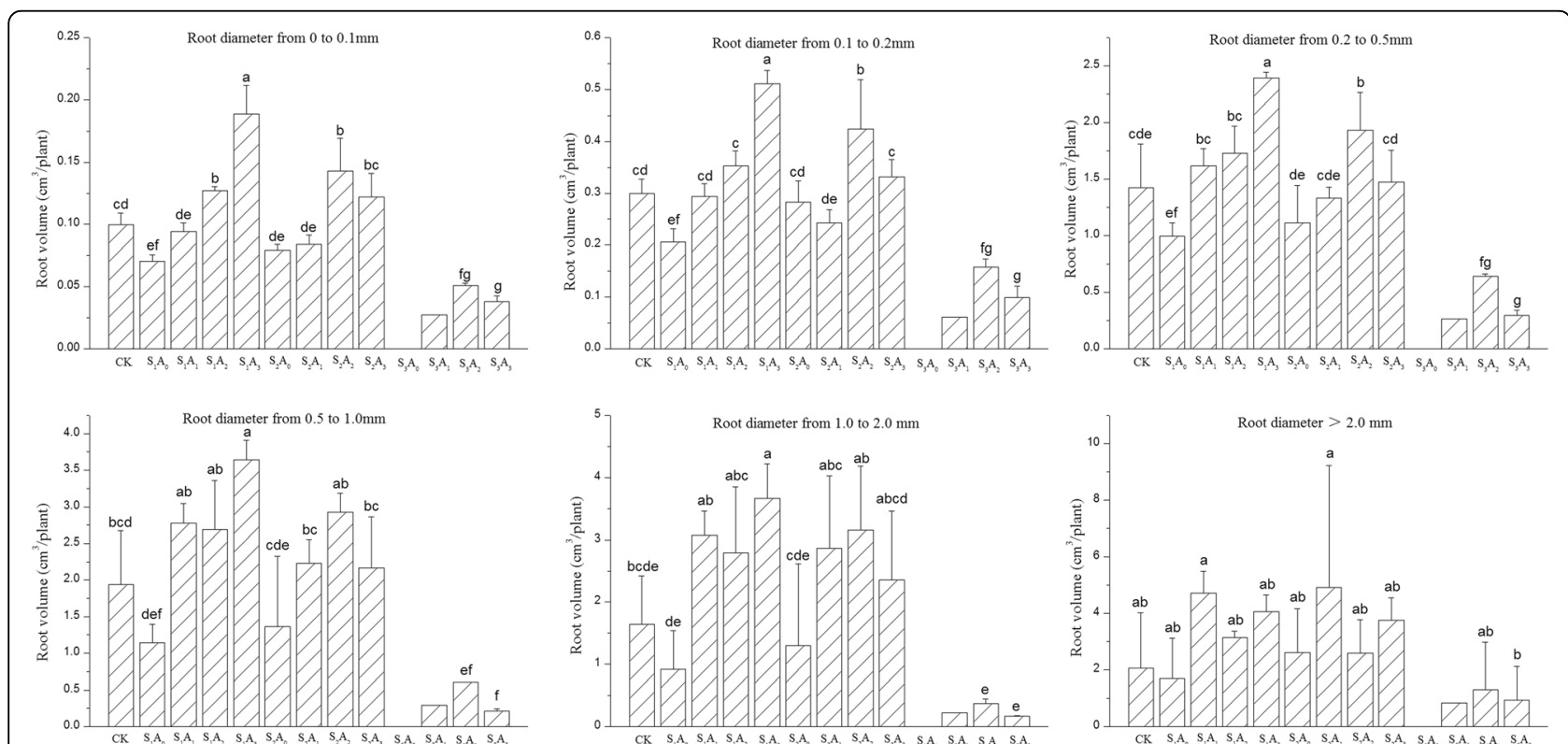

Fig. 3 Effects of $\mathrm{NaCl}$ stress and soil aeration on root volume ( $\mathrm{cm} 3 /$ plant) distribution by root diameter for potted tomato. Columns with the same letter represent values that are not significantly different at the $5 \%$ level of probability according to the Duncan's new multiple-range test. Under the S3A0 treatment plants all died, So the S3A0 column is empty. Multiple comparison can't be performed for S3A1 treatment because only 1 plant survived 

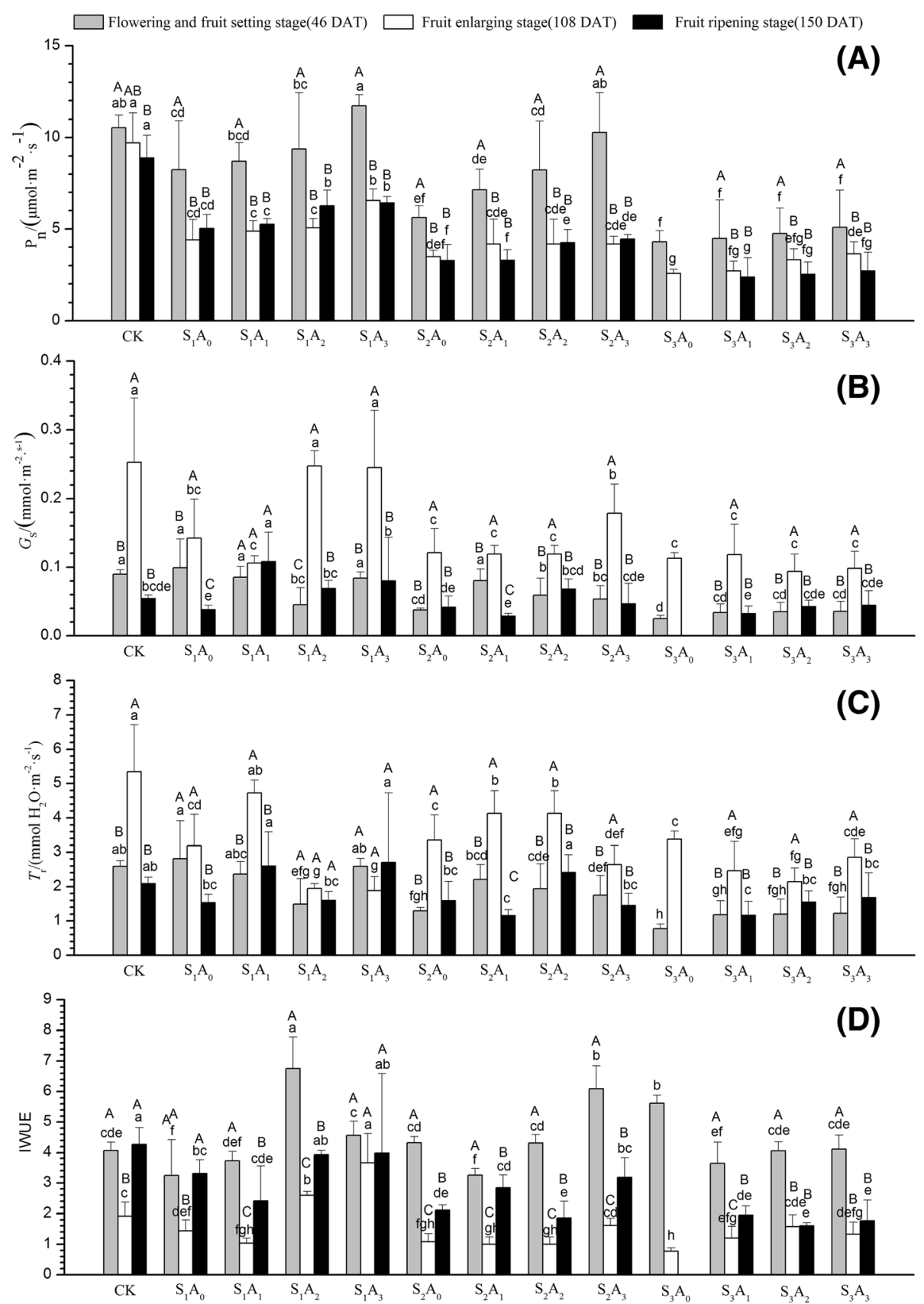

Fig. 4 Effects of $\mathrm{NaCl}$ stress and soil aeration on (a) net photosynthetic rate (Pn), (b) stomatal conductance (Gs), (c) transpiration rate (Tr) and (d) instantaneous water use efficiency at different growth stages for potted tomato. Columns with the same letter represent values that are not significantly different at the $5 \%$ level of probability according to the Duncan's new multiple-range test for different treatments at same growth stage, and same capital letter represent values that are not significantly different at the $5 \%$ level of probability according to the Duncan's new multiple-range test at different growth stage for the same treatments. At the fruit ripening stage, under the S3A0 treatment plants all died, so the column is empty

Gang" was sown in commercial seedling plugs. The tested soil was sourced from the surface $(0-20 \mathrm{~cm}$ depth) of an experimental field at Northwest A\&F University $\left(34^{\circ} 16^{\prime} \mathrm{N}, 108^{\circ} 04^{\prime} \mathrm{E}\right)$. All the processes are legitimate. The soil texture was clay loam (sand
24.5\%; silt 33.2\%; and clay 42.3\%; classified as Inceptisol based on the U.S. soil taxonomy). The soil properties were as follows: electrical conductivity $364.2 \mu \mathrm{S} / \mathrm{cm}$, redox potential $-53.4 \mathrm{mV}$, bulk density $1.35 \mathrm{~g} \mathrm{~cm}^{-3}$, field capacity $26.6 \%$ (by weight), $\mathrm{pH} 7.91$. 


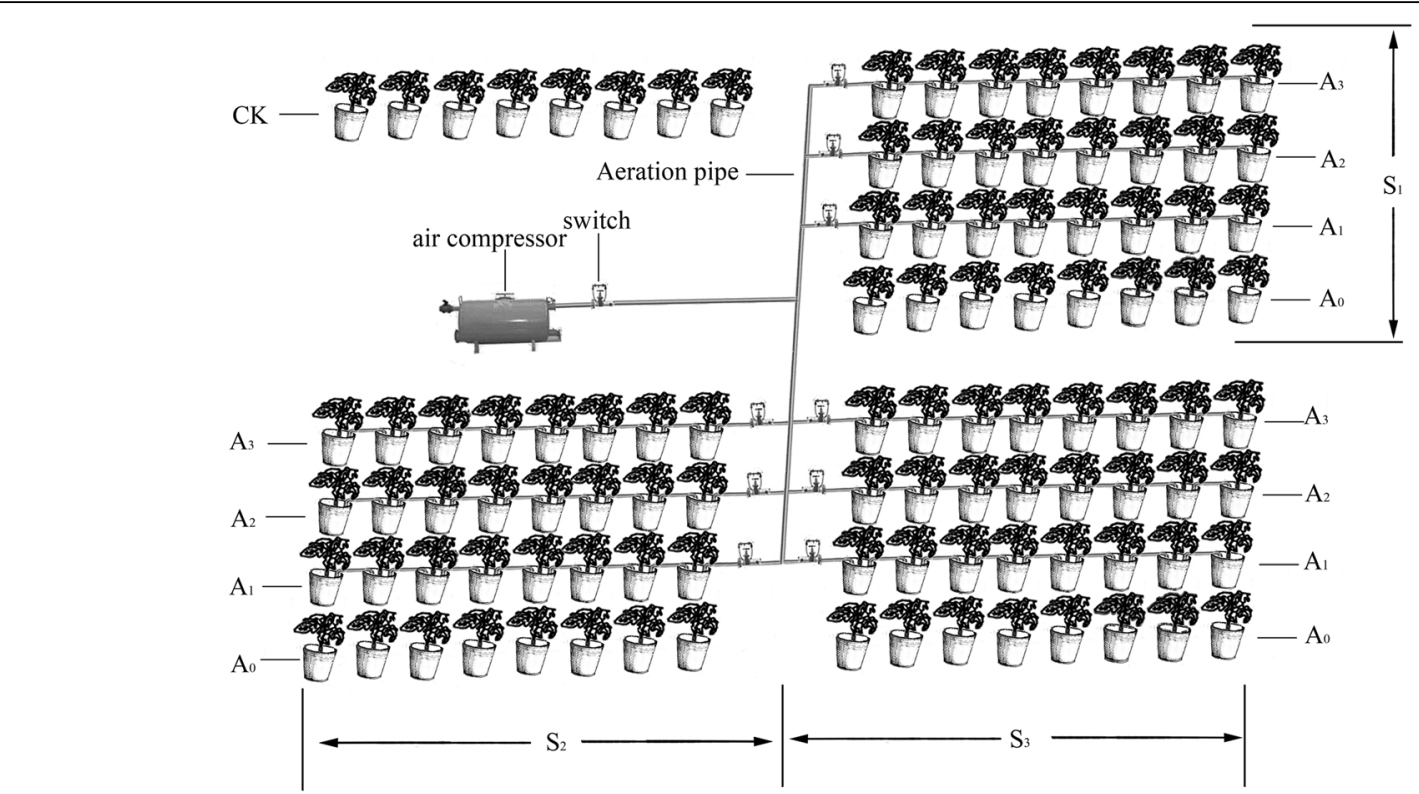

Fig. 5 Sketch map of potted tomato plants at different $\mathrm{NaCl}$ stress and soil aeration levels. Notes: A0, A1, A2, and A3 represent aeration volume are non-aeration, 2.3, 4.6 and 7.0 L/pot, respectively. S1, S2 and S3 represent light, moderate and heavy NaCl stress, respectively. $\mathrm{No} N a C l$ stress with non-aeration served as control and was identified by the designation CK

The ion concentrations of the tested soil were: 3.5 $\mathrm{mMK} \mathrm{K}^{+}, 6.3 \mathrm{mM} \mathrm{Na}{ }^{+}, 11.1 \mathrm{mM} \mathrm{Ca}{ }^{2+}, 4.7 \mathrm{mM} \mathrm{Mg}^{2+}$, $6.4 \mathrm{mM} \mathrm{SO}_{4}{ }^{2-}, 27.2 \mathrm{mM} \mathrm{NO}_{3}{ }^{-}$, and $4.6 \mathrm{mM} \mathrm{Cl}^{-}$.

\section{Experimental design}

Tomato seeds were sown in commercial seedling plugs and transplanted to 104 experimental pots with seedlings of the same growth vigor after 20 days. Fertilizers were applied as basal fertilizer and evenly mixed into the soil at the commencement of the experiment. Before transplanting, carbendazim was used as an antiseptic, and $28 \mathrm{~g} /$ pot of decomposed organic manure (pig and sheep manure), $13.6 \mathrm{~g} /$ pot of diammonium phosphate $(\mathrm{N}$ $\left.18 \%, \mathrm{P}_{2} \mathrm{O}_{5} 46 \%\right)$ and $6 \mathrm{~g} /$ pot of compound fertilizer $(\mathrm{N}$ $\left.18 \%, \mathrm{P}_{2} \mathrm{O}_{5} 15 \%, \mathrm{~K}_{2} \mathrm{O} 12 \%\right)$ were mixed uniformly as basal fertilizer in the soil. Mulching film and $3.5 \mathrm{l}$ of water were added to each pot on the transplanting day. After transplanting, $0.8 \mathrm{l}$ of water was added to each pot every 4 days. Plastic barrels had an upper inner diameter of $28.5 \mathrm{~cm}$ and a bottom inner diameter of $21 \mathrm{~cm}$. We placed a plastic hose with an inner diameter of $6 \mathrm{~mm}$ in spiral form at the bottom of the plastic barrel. The hose has eight special air outlets in its wall; each hole's diameter is $2 \mathrm{~mm}$ and every three holes' interval is $10 \mathrm{~cm}$. The pipe was connected to an air compressor that provided aeration once every 2 days. To prevent clogging, the air outlets and soil were separated by gauze and then the soil was loaded layer by layer until there was $13 \mathrm{~kg}$ soil in the barrel.

The experimental design was treated as a 3 (salinity levels) $\times 4$ (aeration volumes) full factorial design versus nonsaline soil with 8 replicates for statistical analyses (Fig. 5). For $\mathrm{NaCl}$ stress treatment, plants were treated with $\mathrm{S}_{1}$ (light $\mathrm{NaCl}$ stress), $29 \mathrm{mM} \mathrm{Na}^{+}, 28 \mathrm{mM} \mathrm{Cl}^{-} ; \mathrm{S}_{2}$ (moderate $\mathrm{NaCl}$ stress), $75 \mathrm{mM} \mathrm{Na}^{+}, 74 \mathrm{mM} \mathrm{Cl}^{-} ; \mathrm{S}_{3}$ (heavy $\mathrm{NaCl}$ stress), 121 $\mathrm{mM} \mathrm{Na}{ }^{+}, 120 \mathrm{mM} \mathrm{Cl}^{-}$. Every 2 days, air was injected into the pots through the pipe by air compressor at approximately 4 to 6 PM during the whole growing season.

The air discharge rate of each pot was approximately $0.20 \mathrm{~L} / \mathrm{min}$. The aeration volume was controlled by aeration time. Four aeration volumes (A) were set for each NaCl-salt level: $A_{0}, A_{1}, A_{2}$, and $A_{3}$ represent nonaeration, $0.5(2.3 \mathrm{~L} /$ pot $), 1.0(4.6 \mathrm{~L} /$ pot $)$ and $1.5(7.0 \mathrm{~L} /$ pot) times the standard aeration volume $(4.64 \mathrm{~L} / \mathrm{pot})$, respectively. Non- $\mathrm{NaCl}$ stress $\left(6.3 \mathrm{mM} \mathrm{Na}{ }^{+}, 4.6 \mathrm{mM} \mathrm{Cl}^{-}\right)$ with no aeration served as a control and was identified by the designation CK. Each treatment was replicated 8 times. Using $50 \%$ of soil porosity as the standard aeration volume $(4.64 \mathrm{~L} / \mathrm{pot})[57,66]$, the porosity $(\mathrm{n})$ of the silty clay loam soil in the pots was estimated as $\mathrm{n}=\left(1-\rho_{\mathrm{b}} / \rho_{\mathrm{p}}\right) \times 100 \% ; \rho_{\mathrm{b}}$ : dry bulk density, $\rho_{\mathrm{p}}$ : particle density. Using the measured $\rho_{\mathrm{b}}=1.35 \mathrm{~g} \mathrm{~cm}^{-3}$ and taking $\rho_{\mathrm{p}}=2.65 \mathrm{~g} \mathrm{~cm}^{-3}$ gives an estimated $n=49.1 \%$. All agronomic management measures taken during the growth period of tomato such as fertilization, agricultural chemical spraying, etc. were consistent with local production practice.

\section{Test items and methods}

Growth rate $(G R)$ was calculated as $G R=\frac{M_{2}-M_{1}}{T_{2}-T_{1}}$, from two measurement times $T_{2}$ and $T_{1}$, and plant height or 
stem diameter was $M_{2}$ and $M_{1}$. The plant height and stem diameter in each plot were measured at $0,30,50$, 70 , and 90 days after transplantation (DAT) using a steel ruler and electronic digital calipers. All measurements were performed before topping.

Net photosynthetic rate $\left(P_{\mathrm{n}}\right)$, stomatal conductance $\left(G_{\mathrm{s}}\right)$, transpiration rate $\left(T_{\mathrm{r}}\right)$ and intercellular $\mathrm{CO}_{2}$ concentration $\left(C_{\mathrm{i}}\right)$ were measured on healthy attached leaves between 9:00 and 11:00 AM on bright, sunny days during the flowering and fruit setting stage (46 DAT), fruit enlargement stage (108 DAT) and fruit ripening stage (150 DAT). The leaf position was the same for all plants, and leaves were adequately lighted. These measurements were made with a LI-6400 portable photosynthesis measurement system (Li-Cor, Inc., Lincoln, Nebraska, USA) with an internal red/blue LED light source (Li-6400-02B, Li-Cor, Lincoln, Nebraska, USA) with irradiance set at $600 \mu \mathrm{mol} \cdot \mathrm{m}^{-2} \mathrm{~s}^{-1}$. The open flow gas exchange flow rate was $500 \mu \mathrm{mol} \cdot \mathrm{s}^{-1}$. The instantaneous water use efficiency (IWUE) was calculated according to $I W U E=P_{\mathrm{n}} / T_{\mathrm{r}}[67,68]$. Chlorophyll $\mathrm{a}$ and $\mathrm{b}$ were measured during the fruit setting stage (46 DAT) and fruit enlargement stage (108 DAT). A 95\% ethanol solution was used to extract the pigments. Chlorophyll $\mathrm{a}$ and $\mathrm{b}$ in the extract were measured by absorbance spectrophotometry (at 665, 649, and $470 \mathrm{~nm}$, respectively) and used to calculate the content of chlorophyll $\mathrm{a}$ and $\mathrm{b}$ and total chlorophyll $(\mathrm{a}+\mathrm{b})$ content in leaves [69].

After the maturation period (155 DAT), the aboveground parts of the tomato plants were removed, and the soil in the pot was placed on a 100-mesh steel sieve, soaked, and gently washed to separate the roots from the soil. The roots were then dried with absorbent paper. The roots were placed on a transparent tray filled with water to a depth of 10 $\mathrm{mm}$. The trays were scanned with an Epson Perfection V700 scanner to obtain a grayscale TIFF image. This image was then analyzed with the WinRHIZO Pro image processing system (Regent Instruments Inc., 2672 Chemin Sainte-Foy, Quebec City, Quebec G1V 1 V4, Canada) to obtain total root length, surface area, volume, and their distribution over diameter ranges ( $\mathrm{D}$ in $\mathrm{mm}$ ) of $0<\mathrm{D} \leq 0.1,0.1<\mathrm{D} \leq 0.2,0.2<$ $\mathrm{D} \leq 0.5,0.5<\mathrm{D} \leq 1.0,1.0<\mathrm{D} \leq 2.0$, and $2<\mathrm{D}$.

\section{Data analysis}

SPSS 22.0 software (IBM Crop., Armonk, New York, NY, USA) was used to analyze the experimental data. Multiple comparisons using Duncan's new multiple-range test were completed whenever the ANOVA indicated significant differences $(P \leq 5 \%)$. Root morphology, plant height, stem diameter and chlorophyll content were analyzed by two- way ANOVA with the factors aeration volume treatment, $\mathrm{NaCl}$ stress and the interactions of aeration volume treatment $\times \mathrm{NaCl}$ stress. Figures were constructed using the graphing software Origin-Pro 8.5 (Origin Lab Corporation, Northampton, MA, USA) and Photoshop CS 5 (Adobe Systems Inc., San Jose, California, USA).

\section{Abbreviations}

ABA: Abscisic acid; Chl. a: Chlorophyll a; Chl. b: Chlorophyll b; Chl. t: Total chlorophyll; $C_{\mathrm{i}}$ : Intercellular $\mathrm{CO}_{2}$ concentration; $G_{\mathrm{s}}$ : Stomatal conductance; IWUE: Instantaneous water use efficiency; $\mathrm{mM}: \mathrm{mmol} / L_{i} P_{\mathrm{n}}$ : Net photosynthetic rate; $T_{r}$ : Transpiration rate

\section{Acknowledgements}

We acknowledge the support of Jun Gu (Institute of Soil and Water Conservation, Northwest A\&F University) for their assistance in the field and laboratory work.

\section{Authors' contributions}

Conceived and designed the experiments: LY and NWQ. Performed the experiments: LY and ZMZ. Analyzed the data: LY, DXH and WJW. Contributed reagents/materials/analysis tools: LY CXS WJW ZMZ ZZX. Wrote the paper: LY. Revised the manuscript: LY, NWQ, CXS and ZZX. All authors have read and approved the manuscript.

\section{Funding}

This work is supported jointly by the National Key Research Project of China "13th Five Year Plan" (No. 2016YFC0400202), Natural Science Foundation of China (No. 41807041; No. 41831284; No. 51679205), Natural Science Foundation of Guangdong Province (No. 2018A0303130149), Science and Technology Program of Guangzhou (No.20181002SF0530). Fundamental Research Funds for the Central Universities (GK201903115), and the Program of Introducing Talents of Discipline to Universities (B16011). The funding bodies were not involved in the design of the study, collection, analysis, and interpretation of data, and in writing the manuscript.

\section{Availability of data and materials}

The datasets used and/or analyzed during the current study are available from the corresponding author on reasonable request.

Ethics approval and consent to participate Not applicable.

Consent for publication

Not applicable.

\section{Competing interests}

The authors declare that they have no competing interests.

\section{Author details}

${ }^{1}$ Northwest Land and Resources Research Center, Shaanxi Normal University, Xi'an 710119, Shaanxi, China. ${ }^{2}$ Institute of Soil and Water Conservation, Northwest A\&F University, No.26 Xinong Road, Yangling, Shaanxi Province 712100, People's Republic of China. ${ }^{3}$ Institute of Water-saving Agriculture in Arid Areas of China (IWSA), Northwest A\&F University, Yangling 712100,

Shaanxi, China. ${ }^{4}$ Institute of Soil and Water Conservation, Chinese Academy of Sciences and Ministry of Water Resources, Yangling 712100, Shaanxi, China. ${ }^{5}$ Key Laboratory of Vegetation Ecology, Ministry of Education, Institute of Grassland Science, Northeast Normal University, Changchun 130024, Jilin Province, China. ${ }^{6}$ State Environmental Protection Key Laboratory of Wetland Ecology and Vegetation Restoration, School of Environment, Northeast Normal University, Changchun 130117, Jilin Province, China.

Received: 14 December 2018 Accepted: 8 July 2019

Published online: 29 July 2019

\section{References}

1. Mahajan S, Tuteja N. Cold, salinity and droughtstresses: an overview. Arch Biochem Biophys. 2005;444:139-58. 
2. Tuteja N. Mechanisms of high salinity tolerance in plants. Methods Enzymol. 2007:428:419-38.

3. Ashraf M, Athar HR, Harris PJC, Kwon TR. Some prospective strategies for improving crop salt tolerance. Adv Agron. 2008;97:45-110.

4. Flowers T, Yeo A. Breeding for salinity resistance in crop plants: where next? Aust J Plant Physiol. 1995;22(6):875-84.

5. Yurtseven E, Kesmez GD, Unlukara A. The effects of water salinity and potassium levels on yield, fruit quality and water consumption of a native central anatolian tomato species (Lycopersicon esculantum). Agr Water Manage. 2005:78(1-2):128-35.

6. Latef AAA. Changes of antioxidative enzymes in salinity tolerance among different wheat cultivars. Cereal Res Commun. 2010;38(1):43-55.

7. Zhao KF, Li FZ. Halophytes in China. Beijing: Science Press; 1999.

8. Short DC, Colmer TD. Salt tolerance in the halophyte halosarcia pergranulata subsp. pergranulata. Ann Bot-London. 1999;83(3):207-13.

9. Suwa R, Nguyen NT, Saneoka H, Moghaieb R, Fujita K. Effect of salinity stress on photosynthesis and vegetative sink in tobacco plants. Soil Sci Plant Nutr. 2006;52(2):243-50.

10. Chen W, Zou D, Guo W, Xu H, Shi D, Yang C. Effects of salt stress on growth, photosynthesis and solute accumulation in three poplar cultivars. Photosynthetica. 2009:47(3):415-21.

11. Katerji N, van Hoorn JW, Hamdy A, Mastrorilli M. Response of tomatoes, a crop of indeterminate growth, to soil salinity. Agr Water Manage. 1998;38(1):59-68.

12. Van Hoorn JW, Katerji N, Hamdy A, Mastrorilli M. Effect of salinity on yield and nitrogen uptake of four grain legumes and on biological nitrogen contribution from the soil. Agr Water Manage. 2001;51(2):87-98.

13. Martinez V, Uchli AL. Salt-induced inhibition of phosphate uptake in plants of cotton (Gossypium hirsutum L.). New Phytol. 1994;126(4):609-14.

14. Zhu JK. Plant salt tolerance. Trends Plant Sci. 2001;6:66-71.

15. Clarkson DT, Marschner H. 1995 Mineral nutrition of higher plants. 2nd edition. London: Academic Press, Ann Bot-London 1996; 78(4):527-528.

16. Ghassemi F, Jakeman AJ, Nix HA. Salinisation of land and water resources: human causes, extent, management and case studies. Sydney: University of New South Wales Press; 1995.

17. Daliakopoulos IN, Tsanis IK, Koutroulis A, Kourgialas NN, Varouchakis AE, Karatzas GP, Ritsema CJ. The threat of soil salinity: a European scale review. Sci Total Environ. 2016;573:727-39.

18. Blokhina O. Antioxidants, oxidative damage and oxygen deprivation stress: a review. Ann Bot-London. 2003;91 (2):179-94.

19. Li C, Bai T, Ma F, Han M. Hypoxia tolerance and adaptation of anaerobic respiration to hypoxia stress in two Malus species. Sci Hortic. 2010;124(2):274-9.

20. Letey J. Aeration, compaction and drainage. California Turfgrass Culture. 1961;11:17-21

21. Barrett-Lennard EG. The interaction between waterlogging and salinity in higher plants: causes, consequences and implications. Plant Soil. 2003;253(1):35-54.

22. FAO. Food and agricultural commodities production for 2013: Production of tomato by countries. http://faostat3.fao.org/browse/Q/QC/E

23. Bethke PC, Drew MC. Stomatal and nonstomatal components to inhibition of photosynthesis in leaves of capsicum annuum during progressive exposure to $\mathrm{NaCl}$ salinity. Plant Physiol. 1992;99:219-26.

24. Flexas J, Bota J, Loreto F, Cornic G, Sharkey TD. Diffusive and metabolic limitations to photosynthesis under drought and salinity in C3 plants. Plants Plant Biol. 2004;6(3):269-79.

25. Rivelli AR, Lovelli S, Perniola M. Effects of salinity on gas exchange, water relations and growth of sunflower (Helianthus annuus). Funct Plant Biol. 2002;12(29):1405-15.

26. Snapp SS, Shennan C. Salinity effects on root-growth and senescence in tomato and the consequences for severity of phytophthora root-rot infection. J Am Soc Hortic Sci. 1994;119(3):458-63.

27. Lovelli S, Scopa A, Perniola M, Di Tommaso T, Sofo A. Abscisic acid root and leaf concentration in relation to biomass partitioning in salinized tomato plants. J Plant Physiol. 2012;169(3):226-33.

28. Chen XM, Dhungel J, Bhattarai SP, Torabi M, Pendergast L, Midmore DJ. Impact of oxygation on soil respiration, yield and water use efficiency of three crop species. J Plant Ecol. 2011;4(4):236-48.

29. Pendergast L, Bhattarai SP, Midmore DJ. Benefits of oxygation of subsurface drip-irrigation water for cotton in a Vertosol. Crop Pasture Sci. 2013;64:1171-81.

30. Li Y, Jia ZX, Niu WQ, Wang JW, Zhang MZ. Effect of post-infiltration soil aeration at different growth stages on growth and fruit quality of dripirrigated potted tomato plants (Solanum lycopersicum). PLoS One. 2015; 10(12):E143322.
31. Li Y, Niu WQ, Wang JW, Liu L, Zhang MZ, Xu J. Effects of artificial soil aeration volume and frequency on soil enzyme activity and microbial abundance when cultivating greenhouse tomato. Soil Sci Soc Am J. 2016;80(5):1208.

32. Li Y, Niu WQ, Xu J, Zhang RC, Wang JW, Zhang MZ. Aerated irrigation enhancing quality and irrigation water use efficiency of muskmelon in plastic greenhouse. Trans Chinese Soc Agric Eng. 2016;32(1):147-54.

33. Li Y, Jia ZX, Niu WQ, Wang JW. Impact of post-infiltration soil aeration at different growth stages of sub-surface trickle-irrigated tomato plants. Int Agrophys. 2016;30(3):1-7.

34. Li Y, Niu WQ, Xu J, Wang JW, Zhang MZ, Lv W. Root morphology of greenhouse produced muskmelon under sub-surface drip irrigation with supplemental soil aeration. Sci Hortic. 2016;201:287-94.

35. Goorahoo D, Carstensen G, Zoldoske D. Using air in sub-surface drip irrigation (SDI) to increase yields in bell peppers. Int Water Irrig. 2002;22(2):39-42.

36. Lin GCS, Ho SPS. China's land resources and land-use change: insights from the 1996 land survey. Land Use Policy. 2003;20:87-107.

37. Zushi K, Matsuzoe N. Seasonal and cultivar differences in salt-induced changes in antioxidant system in tomato. Sci Hortic. 2009;120(2):181-7.

38. Boyer JS. Plant productivity and environment. Science. 1982;218:443-8.

39. Flores P, Botella MA, Martinez V, Cerda A. Response to salinity of tomato seedlings with a split root system: nitrate uptake and reduction. J Plant Nutr. 2002;25(1):177-87.

40. Shafi M, Zhang G, Bakht J, Khan MA, Ejaz-ul-Islam, Khan MD, Raziuddin. Effect of cadmium and salinity stresses on root morphology of wheat. Pak J Bot. 2010;42(4):2747-54.

41. Gao P, Bai X, Yang L, Lv D, Pan X, Li Y, Cai H, Ji W, Chen Q, Zhu Y. OsaMIR393: a salinity- and alkaline stress-related microRNA gene. Mol Biol Rep. 2011;38(1):237-42

42. Hu X, Zhang Y, Shi Y, Zhang Z, Zou Z, Zhang H, Zhao J. Effect of exogenous spermidine on polyamine content and metabolism in tomato exposed to salinity-alkalinity mixed stress. Plant Physiol Bioch. 2012:57:200-9.

43. Gómez-Bellot MJ, Álvarez S, Castillo M, Bañón S, Ortuño MF, Sánchez-Blanco MJ. Water relations, nutrient content and developmental responses of Euonymus plants irrigated with water of different degrees of salinity and quality. J Plant Res. 2013;126(4):567-76.

44. Chuan CL, Ching HK. Cell wall peroxidase activity, hydrogen peroxide level and NaCl-inhibited root growth of rice seedlings. Plant Soil. 2001;230(1):135-43.

45. Croser C, Renault S, Franklin J, Zwiazek J. The effect of salinity on the emergence and seedling growth of Picea mariana, Picea glauca, and Pinus banksiana. Environ Pollut. 2001;115(1):9-16.

46. Chartzoulakis K, Loupassaki M, Bertaki M, Androulakis I. Effects of $\mathrm{NaCl}$ salinity on growth, ion content and $\mathrm{CO}_{2}$ assimilation rate of six olive cultivars. Sci Hortic. 2002:96(1-4):235-47.

47. Paranychianakis NV, Chartzoulakis KS. Irrigce water: from physiology to management practices. Agric Ecosyst Environ. 2005;106(2-3):171-87.

48. Moghaieb R, Tanaka N, Saneoka H, Hussein HA, Yousef SS, Ewada M, Aly M, Fujita K. Expression of betaine aldehyde dehydrogenase gene in transgenic tomato hairy roots leads to the accumulation of glycine betaine and contributes to the maintenance of the osmotic potential under salt stress. Soil Sci Plant Nutr. 2000;46(4):873-83.

49. JEscalona JF, Medrano H. Water stress induces different levels of photosynthesis and electron transport rate regulation in grapevines. Plant Cell Environ. 1998;22:39-48.

50. Koyro HW. Effect of salinity on growth, photosynthesis, water relations and solute composition of the potential cash crop halophyte Plantago coronopus (L.). Environ Exp Bot. 2006;56(2):136-46.

51. Serrano R, Rodriguez-Navarro A. loct stress in plants. Curr Opin Cell Biol. 2001:13:399-404.

52. Morard P, Silvestre J. Plant injury due to oxygen deficiency in the root environment of soilless culture: a review. Plant Soil. 1996;184(2):243-54.

53. Morard P, Lacoste L, Silvestre J. Effect of oxygen deficiency on uptake of water and mineral nutrients by tomato plants in soilless culture. J Plant Nutr. 2000;23(8):1063-78.

54. Horchani F, Gallusci P, Baldet P, Cabasson C, Maucourt M, Rolin D, AschiSmiti S, Raymond P. Prolonged root hypoxia induces ammonium accumulation and decreases the nutritional quality of tomato fruits. J Plant Physiol. 2008;165(13):1352-9.

55. Bhattarai SP, Pendergast L, Midmore DJ. Root aeration improves yield and water use efficiency of tomato in heavy clay and saline soils. Sci Hortic. 2006;108(3):278-88. 
56. Shahien MM, Abuarab ME, Magdy E. Root aeration improves yield and water use efficiency of irrigated potato in sandy clay loam soil. Int J Adv Res. 2014;2(10):310-20.

57. Niu WQ, Jia ZX, Zhang $X$, Shao HB. Effects of soil rhizosphere aeration on the root growth and water absorption of tomato. Clean-Soil, Air, Water. 2012:40(12):1364-71.

58. Fukao T, Xu K, Ronald PC, Baileyserres JA. Variable cluster of ethylene response factor-like genes regulates metabolic and developmental acclimation responses to submergence in rice. Plant Cell. 2006;18(8):2021-34.

59. Belin C, Thomine S, Schroeder Jl. Water balance and the regulation of stomatal movements. In: Abiotic stress adaptation in plants. Dordrecht: Springer; 2009

60. Lovelli S, Scopa A, Perniola M, Tommaso TD, Sofo A. Abscisic acid root and leaf concentration in relation to biomass partitioning in salinized tomato plants. J Plant Physiol. 2012:169(3):226-33.

61. Olds CL, Glennon EKK, Luckhart S. Abscisic acid: new perspectives on an ancient universal stress signaling molecule. Microbes Infect. 2018;20:484-92.

62. Kim T, Böhmer M, Hu H, Nishimura N, Schroeder Jl. Guard cell signal transduction network: advances in understanding abscisic acid, $\mathrm{CO}_{2}$, and $\mathrm{Ca}^{2+}$ signaling. Annu Rev Plant Biol. 2010;61(1):561-91.

63. Pezeshki SR. Differences in patterns of photosynthetic responses to hypoxia in flood-tolerant and flood-sensitive tree species. Photosynthetica. 1993;28(3):423-30.

64. Else MA, Tiekstra AE, Croker SJ, Davies WJ, Jackson MB. Stomatal closure in flooded tomato plants involves abscisic acid and a chemically unidentified anti-transpirant in xylem sap. Plant Physiol. 1996;112:239-47.

65. Bai T, Li C, Li C, Liang D, Ma F. Contrasting hypoxia tolerance and adaptation in Malus species is linked to differences in stomatal behavior and photosynthesis. Physiol Plant. 2013;147(4):514-23.

66. Li Y, Niu WQ, Wang JW, Zhang MZ. Effects of aeration on rhizosphere soil enzyme activities and soil microbes for muskmelon in plastic greenhouse. Trans Chinese Soc Agric Mach. 2015;46(08):121-9.

67. Ramírez DA, Valladares F, Domingo F, Bellot J. Seasonal water-use efficiency and chlorophyll fluorescence response in alpha grass (Stipa tenacissima L.) is affected by tussock size. Photosynthetica. 2008;46(2):222-31.

68. Zhang LD, Gao LH, Zhang LX, Wang $S Z$, Sui XL, Zhang ZX. Effects of alternative furrow irrigation and nitrogen application rate on photosynthesis, growth,and yield of cucumber in solar greenhouse. Chin J Appl Ecol. 2011;09:2348-54

69. Liu JY, Liu X. Experiment of plant physiology, higher education press. Beijing, China. 2010,

\section{Publisher's Note}

Springer Nature remains neutral with regard to jurisdictional claims in published maps and institutional affiliations.

Ready to submit your research? Choose BMC and benefit from:

- fast, convenient online submission

- thorough peer review by experienced researchers in your field

- rapid publication on acceptance

- support for research data, including large and complex data types

- gold Open Access which fosters wider collaboration and increased citations

- maximum visibility for your research: over $100 \mathrm{M}$ website views per year

At $\mathrm{BMC}$, research is always in progress.

Learn more biomedcentral.com/submissions 